\title{
ENSO and PDO Effects on Hydroclimatic Variations of the Upper Colorado River Basin
}

\author{
Hugo G. Hidalgo and John A. Dracup \\ Civil and Environmental Engineering Department, University of California, Berkeley, Berkeley, California
}

(Manuscript received 4 June 2001, in final form 6 June 2002)

\begin{abstract}
Linkages between tropical Pacific Ocean monthly climatic variables and the Upper Colorado River basin (UCRB) hydroclimatic variations from 1909 to 1998 are analyzed at interseasonal timescales. A study of the changes in these linkages through the years and their relationship to the Pacific Decadal Oscillation (PDO) is also investigated. Tropical Pacific climate variations were represented by atmospheric/oceanic ENSO indicators. For the UCRB, warm season (April-September) streamflow totals at Lee's Ferry, Arizona, and precipitation averages at different periods (cold season: October-March; warm season: April-September; and annual: OctoberSeptember) were used to study the UCRB's response to tropical Pacific climatic forcing. A basinwide ENSO signature was found in the significant correlations between warm season precipitation in the UCRB and warm season SST averages from the Niño-3 region in most of the stations around the UCRB. This link is more evident during the warm phase of ENSO (El Niño), which is associated with an increase in warm season precipitation. The analysis also showed a link between June to November ENSO conditions and cold season precipitation variations contained in a principal component representing the high-elevation precipitation stations, which are the main source of streamflow. However, the amplitude and coherence of the cold season ENSO signal is significantly smaller compared to the general precipitation variations found in stations around the UCRB. Only when very few stations in the high elevations are considered is the ENSO signal in cold season precipitation in the basin revealed. Interdecadal hydroclimatic variations in the UCRB related to possible PDO influences were also investigated. There are significant shifts in the mean of UCRB's moisture-controlled variables (precipitation and streamflow) coincident with the PDO shifts, suggesting a connection between the two processes. It has been suggested in other studies that this connection could be expressed as a modulation on the predominance of each ENSO phase; that is, strong and consistent winter El Niño (La Niña) patterns are associated with the positive (negative) phase of the PDO. In the UCRB this apparent modulation seems to be accompanied by a general change in the sign of the correlation between ENSO indicators and cold season precipitation in most stations of the basin around 1932/33. From 1909 to 1932 the basin has a predominantly cold season ENSO response characteristic of the northwestern United States (drier than normal associated with tropical SST warming and vice versa); from 1933 to 1998 the response of the basin is predominantly typical of the southwestern United States during winter (wetter than normal associated with tropical SST warming and vice versa). This apparent correlation sign reversal is suggested to be related to interdecadal changes in the boundary of the north-south bipolar response characteristic of the ENSO signal in the western United States during winter.
\end{abstract}

\section{Introduction}

Hydroclimatic variations in the Upper Colorado River basin (UCRB) are linked to climate variations in the tropical Pacific Ocean in this study. Changes in these linkages for different epochs are also studied, with the objective of better characterizing the dependency of the UCRB's hydroclimate on the Pacific Ocean's oceanic and atmospheric processes.

The influence of the tropical Pacific climate conditions in the form of El Niño-Southern Oscillation (ENSO) events to North American hydroclimatic vari-

Corresponding author address: Dr. Hugo G. Hidalgo, Department of Civil and Environmental Engineering, 631 Davis Hall \#1710, Berkeley, CA 94720-1710.

E-mail: hidalgo@ce.berkeley.edu ability has been well documented (e.g., Ropelewski and Halpert 1986, 1989; Kiladis and Diaz 1989; Cayan and Webb 1992; Kayha and Dracup 1993, 1994; Redmond and Koch 1991; Piechota and Dracup 1996, 1999; Piechota et al. 1997; Gershunov 1998; Dettinger et al. 1998, 1999; Higgins et al. 2000). In general, southwestern U.S. cold season precipitation tends to be wetter than normal during El Niño events (negative phase of the Southern Oscillation) and drier than normal during $\mathrm{La}$ Niña events (positive phase of the Southern Oscillation). The opposite effect is observed for the northwestern United States, creating a bipolar response between the two regimes (Ropelewski and Halpert 1986; Cayan and Webb 1992; Cayan et al. 1999). North-south contrast in zonal precipitation is also related to ENSO. The latitudinal center of winter zonal precipitation shifts south 
TABle 1. Partial list of references citing effects of North Pacific climate variation.

\begin{tabular}{|c|c|c|}
\hline Reference & Variable studied/affected & Region \\
\hline Ebbesmeyer et al. (1991) & 40 physical and environmental variables & Pacific basin \\
\hline Kerr (1992) & $\begin{array}{l}\text { Hydroclimate (general discription of the 1976/77 } \\
\text { shift) }\end{array}$ & Pacific Ocean \\
\hline Beamish (1993) & Increase in fish production & North American west coast \\
\hline Trenberth and Hurrell (1994) & $\begin{array}{l}\text { Eastward shift in Aleutian low pressure system; } \\
\text { anomalous circulation in upper-troposphere affects } \\
\text { temperature, rainfall, streamflow, and fish produc- } \\
\text { tivity }\end{array}$ & North Pacific Ocean ${ }^{\mathrm{a}}$ \\
\hline Diaz and Pulwarty (1994) & $\begin{array}{l}\text { Seven climatic ENSO-sensitive indices, including pa- } \\
\text { leoclimatic records }{ }^{\mathrm{b}}\end{array}$ & Periphery of the Indian and Pacific Oceans \\
\hline McCabe and Fountain (1995) & $\begin{array}{l}\text { Changes in glacial winter mass balance caused in part } \\
\text { by winter atmospheric circulation changes }\end{array}$ & South Cascade glacier, Washington ${ }^{\mathrm{c}}$ \\
\hline Dettinger and Cayan (1995) & Increase in snowmelt and runoff & Central California \\
\hline Beamish et al. (1995) & $\begin{array}{l}\text { Chinook salmon productivity changes; synchronous } \\
\text { increase in mean temperature, decline in river } \\
\text { flows, decrease in marine survival of hatchery- } \\
\text { reared Chinook }\end{array}$ & Strait of Georgia, Fraser River \\
\hline Deser et al. (1996) & Anomalous upper-ocean temperature profiles $0-400 \mathrm{~m}$ & North Pacific Ocean \\
\hline Pelto (1996) & $\begin{array}{l}\text { Annual net balance changes on eight glaciers during } \\
\text { 1984-94 }\end{array}$ & North Cascade glaciers, Washington \\
\hline Horner et al. (1997) & Increase in harmful algal blooms & U.S. West Coast \\
\hline Piechota et al. (1997) & Streamflow ${ }^{\mathrm{d}}$ & Western U.S. \\
\hline Zhang and Levitus (1997) & Upper-ocean temperature anomalies & North Pacific Ocean ${ }^{e}$ \\
\hline Beamish et al. (1997a) & Increase abundance of Pacific salmon & North Pacific Ocean \\
\hline Beamish et al. (1997b) & Changes in abundance of sockeye salmon & Fraser River \\
\hline Conversi and Hameed (1997) & $\begin{array}{l}\text { Zooplankton biomass and sea surface temperature } \\
\text { changes }^{\mathrm{f}}\end{array}$ & Gulf of Alaska \\
\hline Mantua et al. (1997) & Changes in salmon production & North Pacific Ocean \\
\hline Weinheimer and Cayan (1997) & Varves from sediment record ${ }^{\mathrm{g}}$ & Santa Barbara, California \\
\hline Zhang et al. $(1997,1998)$ & $\begin{array}{l}\text { Global sea surface temperature, sea level pressure, } \\
\text { and other related variables }\end{array}$ & Pacific Ocean \\
\hline Wiles et al. (1998) & Tree ring records and reconstructed temperature & Gulf of Alaska \\
\hline Brown and Braaten (1998) & Changes in snow-depth records & Canada \\
\hline Niebauer (1998) & $\begin{array}{l}\text { Winter sea level pressure, Bering Sea ice cover } \\
\text { change, Southern Oscillation index, and western } \\
\text { Pacific oscillation }\end{array}$ & Northern Hemisphere \\
\hline McGowan et al. (1998) & Marine populations & U.S. West Coast \\
\hline Downton and Miller (1998) & Salmon production & Alaska \\
\hline Swetnam and Betancourt (1998) & $\begin{array}{c}\text { Ecological response variables: fires, insect outbreaks, } \\
\text { pulses in tree demography, and tree ring records }\end{array}$ & Southwestern U.S. \\
\hline Hare and Mantua (2000) & $\begin{array}{l}100 \text { environmental time series: } 31 \text { climatic and } 69 \text { bi- } \\
\text { ological }\end{array}$ & North American coast, including Alaska \\
\hline
\end{tabular}

a Coupled also with tropical Pacific forcing.

${ }^{b}$ Spectral and cross-spectral analysis of these variables was studied.

c The glacier is affected by changes in the winter circulation patterns over the North Pacific and Canada.

d Principal components extracted from 79 streamflow stations for ENSO years.

${ }^{\mathrm{e}}$ Connection mechanisms (bridge) between tropical and extratropical regions.

$\mathrm{f}$ This study was focused on the finding of a 28.8-month signal corresponding to the quasi-biennial oscillation in these variables.

g Strong interdecadal signal was found in these varves, which were not very sensitive to ENSO.

with tropical warming and vice versa (Dettinger et al. 1998).

In recent years, an increased interest in the contribution of North Pacific decadal-scale climate variations to the North American physical environment has captivated considerable research efforts (Table 1). North Pacific decadal-scale oceanic variations are present in at least two of the first six rotated global modes of nonENSO SST variability found by Mestas-Nuñez and Enfield (1999; Enfield and Mestas-Nuñez 1999), explaining a combined $13.2 \%$ of the variance. Two rotated principal components of monthly SST variability from a region of the Pacific Ocean from $20^{\circ} \mathrm{S}$ to $60^{\circ} \mathrm{N}$ latitude are related to precipitation, drought, and streamflow in the United States (Nigam et al. 1999; Barlow et al. 2001).

Decadal-scale climatic variations in the North Pacific drive episodic changes on climatic conditions over relatively short periods of time known as climatic regime shifts (Minobe 1999; Mantua et al. 1997). These shifts have significant effects on the North American physical environment, evidenced as steps in the mean and/or the variance of physical records such as glacial mass, streamflow, marine populations, ecological response variables, and fire frequency changes (Table 1).

The most extensively studied climate regime shift oc- 
curred in 1976/77, a period characterized by a significant step in the mean toward wetter conditions in physical and environmental variables around the Pacific basin. This shift is strongly evident as a single event in the physical records of some regions (Ebbesmeyer et al. 1991; Trenberth 1990; Graham 1994), while in other studies (Mantua et al. 1997; Hare and Francis 1995; Minobe 1997; Zhang et al. 1997), the 1976/77 shift is just one realization of multiple shifts recorded in physical and environmental variables. These shifts are linked to a quasi-oscillatory mechanism associated with sign reversals of SST anomalies from an extensive region of the North Pacific (Mantua et al. 1997), and they are evident in November-March averages of the North Pacific SST leading principal component (PC), designated the Pacific Decadal Oscillation (PDO) index by Mantua et al. (1997). Additional sign reversals of the PDO index were recorded in 1924/25 and 1946/47, impacting physical and environmental variables around the North American coast (Mantua et al. 1997).

Anomalies in the oceanic component, which are more slowly varying and therefore contain a longer memory, are coupled with atmospheric pressure patterns having higher-frequency variations, which in turn produce changes in atmospheric wave and jet stream patterns, influencing regional temperature, precipitation and storm track location and intensity, and ultimately climatic variations at later seasons (Cayan 1992; Cayan and Webb 1992; Cayan et al. 1998; Dettinger et al. 1998; Trenberth 1990; Trenberth and Hurrell 1994). General references of ocean-atmosphere interactions can be found in Alexander et al. (1999). For the North Pacific in particular, Namias (1969) presented correlation maps between SST and sea level pressure (SLP) fields by season during the 1960s. Similar ocean-atmosphere field correlations for the period 1951-80 can be found in Trenberth and Hurrell (1994). In this latter study, the authors estimated the lag between SST and atmospheric circulation in the North Pacific to be from 1 to 2 months. Using an atmospheric general circulation model, Volodin and Galin (1999) showed that differences between the periods 1946-76 and 1977-88 in the Northern Hemisphere near-surface temperature and pressure are related to SST variation. Finally, the strength and position of the wintertime Aleutian low is usually related to the interannual sign of the PDO index. A deeper and eastward-shifted Aleutian low is typical of the positive PDO phase (Mantua et al. 1997; Trenberth 1990; Trenberth and Hurrell 1994). The generally deeper Aleutian low after the 1976/77 climate regime shift was associated with advection of warmer and moister air to the North American west coast and colder air over the North Pacific, producing changes in atmospheric thermodynamic and moisture-carrying mechanisms, as well as altered ocean currents (Ingraham et al. 1991) and coastal SSTs (Trenberth and Hurrell 1994). These changes manifested as southward shifts of normal storm tracks, changes in the physical environment, and anomalous rainfall and streamflow patterns (Trenberth and Hurrell 1994). Changes in climatic conditions produced alterations in marine life, manifested in the general increase in the productivity of many fish species after the 1976/77 shift (Trenberth and Hurrell 1994; Mantua et al. 1997; Hollowed et al. 2001).

Although a strong connection between tropical and North Pacific climatic variations is generally accepted (Zhang and Levitus 1997; Zhang et al. 1997, 1998; Liu and Zhang 1999), at this time researchers are only beginning to fully understand coupling mechanisms and bridges between the two regions. Understanding the forcing mechanisms that affect hydroclimatic conditions in the UCRB will provide useful information for forecasting models (Hamlet and Lettenmaier 1999; Latif and Barnett 1996) and for water resources planning. In the following sections, we will present evidence of the ENSO and PDO signature in the UCRB. These effects are manifested differently in warm and cold season precipitation, as well as in streamflow; for this reason separate analyses for these variables are presented.

\section{Data sources and characteristics}

\section{a. Streamflow}

The streamflow dataset most commonly used for characterizing hydrologic variation in the UCRB is the Lee's Ferry record. Lee's Ferry, Arizona, is located 1 mile downstream of the confluence of the Colorado and the Paria Rivers, at the legal dividing point between the Upper and the Lower Colorado River basins. A monthly adjusted unimpaired streamflow record for Lee's Ferry from 1906 to 1998 was obtained from the U.S. Bureau of Reclamation (USBR 1998). The data were adjusted by the USBR to account for upstream regulation and consumption, especially important after 1963, when operation of the Glen Canyon Dam and the filling of Lake Powell began. However, streamflow estimates prior to 1914 are less reliable, since the data were extrapolated from stations outside the basin (Stockton and Jacoby 1976). Data from 1914 to 1922 are compiled from estimates of the streamflows of the three main tributaries (Colorado, Green, and San Juan Rivers) and are considered accurate enough for hydrologic studies (Stockton and Jacoby 1976). A stream gauge was installed in 1923, reducing uncertainties associated with data collection from that time forward. The quality of the data after these adjustments is difficult to quantify; however, the annual averages of the streamflow record from 1909 to 1998 are strongly correlated with the basinwide annual averages of the Palmer drought hydrological index $(r=0.82)$ and precipitation $(r=0.76)$ in the basin (see next section), giving us confidence that the streamflow data contains an underlying hydroclimatic signal. Additionally, these high correlations are maintained in the first and the second halves of the records. 


\section{b. Precipitation}

Monthly precipitation totals for stations around the UCRB were obtained from the National Climatic Data Center (NCDC 1999). The Global Historical Climatology Network (GHCN) dataset was updated using the Cooperative Station (COOP) dataset, both of which are from the NCDC. In addition, some of the Colorado station data were obtained from the Colorado Data Center (CDC) at Colorado State University. Stations showing a discrepancy in the data obtained from different sources of more than $38 \mathrm{~mm}$ in any given month were not used in the analysis. In cases when discrepancies below this threshold were found, averages were computed from the values reported by different sources. Only stations with data covering at least the 1931-98 period were considered as candidates for the analysis, and in some cases only the stations with data from 1909 to 1998 were used. The 1931-98 period was selected in many analyses to maximize the number of stations (high spatial resolution) while attempting to maintain the longest possible records. Additionally, stations with more than 5\% missing data were not used. Missing values were estimated from a weighted average using the monthly means from the known data and the precipitation values from the neighboring 4 months. All resulting time series were visually inspected for outliers. In Table 2, the list of precipitation stations used in this study is shown. Figure 1 shows the monthly distribution of a subset of stations representing different elevations.

Since the UCRB comprises a highly varied selection of elevations and climate regimes, it is difficult to integrate all precipitation contributions into a single time series that is highly representative of the entire-basin precipitation. Basinwide precipitation estimates were obtained from a principal component analysis (Table 3; Fig. 2). The first component (PC1) is highly correlated with precipitation variations from most stations in the basin and is also highly correlated $(r=0.94)$ with an alternative basinwide precipitation estimation obtained by averaging data from the climate divisions covering the basin (not shown). Since the highly productive cold season regions (responsible for most of the runoff) represent only a small percentage of the basin's area (see section 3a), the basinwide estimation represented by PC1 is biased toward the precipitation variations of the low and middle-elevation stations. This is also confirmed by the significant correlations found between warm season averages of the Niño-3 SST anomalies and PC1 (Table 3). In order to account for the cold season signal in the high elevations we included PC5 in part of the analysis (Fig. 2). Cold season variations of PC5 were shown to be strongly correlated with June-November averages of Niño-3 SST anomalies (4 months in advance) (Table 3 ). This lag was selected according to Redmond and Koch (1991), who related the Southern Oscillation Index (SOI) to climate division precipitation in the United States. Despite the high correlations found between PC5 and ENSO indicators, it should be noted that the significantly lower maximum loadings (Fig. 2) and the lower variance explained by this PC (Table 3) suggest that this signal is significantly weaker and less coherent than PC1. It also should be noted that the loading pattern of PC5 suggests that the boundary of the north-south bipolar response characteristic of the ENSO signal in the western United States during winter crosses through the basin. This implies that some parts of the basin present the characteristic ENSO response of the northwestern United States (wet conditions during La Niña and vice versa); while other parts present the typical ENSO response of the southwestern United States (wet conditions during El Niño and vice versa).

\section{c. Sea surface temperature}

A $5^{\circ} \times 5^{\circ}$ grid of monthly Pacific Ocean sea surface temperature (SST) anomalies data from 1856 to 1999 was obtained from an updated version of the Kaplan et al. (1998) dataset. The data were interpolated from ship observations from the U.K. Meteorological Office database (Parker et al. 1994) using optimal estimation from 80 empirical orthogonal functions. Sea surface temperature anomaly time series for regions Niño1 $+2\left(0^{\circ}-\right.$ $\left.10^{\circ} \mathrm{S}, 90^{\circ}-80^{\circ} \mathrm{W}\right)$, Niño-3 $\left(5^{\circ} \mathrm{N}-5^{\circ} \mathrm{S}, 150^{\circ}-90^{\circ} \mathrm{W}\right)$, and Niño-4 $\left(5^{\circ} \mathrm{N}-5^{\circ} \mathrm{S}, 170^{\circ}-120^{\circ} \mathrm{W}\right)$ were averaged from the gridded data.

\section{d. Other indices}

The SOI data from 1866 to 1998 (Chelliah 1990) were obtained from the Joint Institute for the Study of the Atmosphere and Ocean database (JISAO 1999). Updated estimates of the Multivariate ENSO Index (MEI) from 1950 to 1998 were obtained from an updated version of the data by Wolter (1987). Tree ring chronologies were obtained from the National Oceanic and Atmospheric Administration (NOAA) International Tree Ring Data Bank (NOAA 1997).

\section{UCBR response to ENSO events}

\section{a. Basinwide analysis}

The UCRB is a semiarid basin covering approximately $280600 \mathrm{~km}^{2}$. It is bordered by two high-elevation mountain ranges: the Rocky Mountains to the east and the Wasatch Mountains to the west. Warm season streamflow variations in the UCRB are heavily dependent upon cold season precipitation stored as snowpack. Although satellite images show that around $65 \%$ of the basin can be covered by snow during an average winter (Josberger et al. 1993), it is estimated that $85 \%$ of the runoff originates from only $15 \%$ of the area (Stockton and Jacoby 1976). This $15 \%$ includes all the very high elevation areas, which have high annual hydrologic yields. The strong dependence of streamflow 
TABLE 2. List of stations used in this study. The station names and (cooperative) station numbers were assigned according to the NCDC listings. The $r_{\text {cold-season }}$ column denotes the correlation between cold season (Oct-Mar) precipitation and the following year's Apr-Sep streamflow totals at Lee's Ferry, AZ.

\begin{tabular}{|c|c|c|c|c|c|}
\hline Station no. & Station name & Lat & Lon & Elevation (m) & $r_{\text {cold-season }}$ \\
\hline $420738-7$ & Blanding & $37^{\circ} 37^{\prime}$ & $-109^{\circ} 29^{\prime}$ & 1841 & 0.45 \\
\hline 051071-1 & Buena Vista & $38^{\circ} 50^{\prime}$ & $-106^{\circ} 8^{\prime}$ & 2426 & 0.23 \\
\hline $051179-4$ & Byers & $39^{\circ} 42^{\prime}$ & $-104^{\circ} 13^{\prime}$ & 1585 & 0.24 \\
\hline 051294-1 & Canon City & $38^{\circ} 27^{\prime}$ & $-105^{\circ} 14^{\prime}$ & 1628 & 0.32 \\
\hline 291664-2 & Chama & $36^{\circ} 55^{\prime}$ & $-106^{\circ} 35^{\prime}$ & 2393 & 0.64 \\
\hline $051528-4$ & Cheesman & $39^{\circ} 13^{\prime}$ & $-105^{\circ} 17^{\prime}$ & 2100 & 0.16 \\
\hline $051741-2$ & Collbran & $37^{\circ} 40^{\prime}$ & $-106^{\circ} 19^{\prime}$ & 1875 & 0.63 \\
\hline $051959-2$ & Crested Butte & $38^{\circ} 52^{\prime}$ & $-106^{\circ} 58^{\prime}$ & 2707 & 0.57 \\
\hline $052192-2$ & Delta & $38^{\circ} 46^{\prime}$ & $-108^{\circ} 4^{\prime}$ & 1561 & 0.14 \\
\hline $052220-4$ & Denver WBFO Airport & $39^{\circ} 45^{\prime}$ & $-104^{\circ} 52^{\prime}$ & 1615 & 0.21 \\
\hline $422101-1$ & Deseret & $39^{\circ} 17^{\prime}$ & $-112^{\circ} 39^{\prime}$ & 1384 & 0.50 \\
\hline $052281-2$ & Dillon & $39^{\circ} 38^{\prime}$ & $-106^{\circ} 2^{\prime}$ & 2679 & 0.19 \\
\hline $482715-4$ & Dubois & $43^{\circ} 32^{\prime}$ & $-109^{\circ} 38^{\prime}$ & 2112 & 0.01 \\
\hline $422253-6$ & Duchesne & $40^{\circ} 10^{\prime}$ & $-110^{\circ} 24^{\prime}$ & 1686 & 0.56 \\
\hline $052432-2$ & Durango & $37^{\circ} 18^{\prime}$ & $-107^{\circ} 51^{\prime}$ & 1996 & 0.50 \\
\hline $422592-4$ & Escalante & $37^{\circ} 46^{\prime}$ & $-111^{\circ} 36^{\prime}$ & 1756 & 0.32 \\
\hline $483099-3$ & Evanston & $41^{\circ} 16^{\prime}$ & $-110^{\circ} 57^{\prime}$ & 2073 & 0.41 \\
\hline $422828-4$ & Fillmore & $38^{\circ} 58^{\prime}$ & $-112^{\circ} 20^{\prime}$ & 1558 & 0.62 \\
\hline $053005-4$ & Fort Collins & $40^{\circ} 35^{\prime}$ & $-105^{\circ} 5^{\prime}$ & 1524 & 0.17 \\
\hline $422996-6$ & Fort Duchesne & $40^{\circ} 17^{\prime}$ & $-109^{\circ} 52^{\prime}$ & 1521 & 0.42 \\
\hline $053357-2$ & Glenwood Springs & $39^{\circ} 33^{\prime}$ & $-107^{\circ} 20^{\prime}$ & 1747 & 0.56 \\
\hline $423415-7$ & Green River $1 \mathrm{SE}$ & $38^{\circ} 59^{\prime}$ & $-110^{\circ} 9^{\prime}$ & 1241 & 0.41 \\
\hline $053662-2$ & Gunnison & $38^{\circ} 32^{\prime}$ & $-106^{\circ} 58^{\prime}$ & 2335 & 0.30 \\
\hline $053867-2$ & Hayden & $40^{\circ} 29^{\prime}$ & $-107^{\circ} 15^{\prime}$ & 1945 & 0.61 \\
\hline $423809-5$ & Heber & $40^{\circ} 30^{\prime}$ & $-111^{\circ} 25^{\prime}$ & 1704 & 0.63 \\
\hline $424856-5$ & Laketown & $41^{\circ} 50^{\prime}$ & $-111^{\circ} 19^{\prime}$ & 1823 & 0.38 \\
\hline $485390-9$ & Lander Hunt Field & $42^{\circ} 49^{\prime}$ & $-108^{\circ} 44^{\prime}$ & 1695 & 0.22 \\
\hline $425065-4$ & Levan & $39^{\circ} 33^{\prime}$ & $-111^{\circ} 52^{\prime}$ & 1618 & 0.66 \\
\hline $425186-3$ & Logan Utah State University & $41^{\circ} 45^{\prime}$ & $-111^{\circ} 48^{\prime}$ & 1381 & 0.58 \\
\hline $055116-4$ & Longmont 2 ESE & $40^{\circ} 10^{\prime}$ & $-105^{\circ} 4^{\prime}$ & 1509 & 0.31 \\
\hline $425402-4$ & Manti & $39^{\circ} 15^{\prime}$ & $-111^{\circ} 38^{\prime}$ & 1731 & 0.69 \\
\hline $425733-7$ & Moab & $38^{\circ} 34^{\prime}$ & $-109^{\circ} 33^{\prime}$ & 1219 & 0.34 \\
\hline $055717-2$ & Montrose 1 & $38^{\circ} 29^{\prime}$ & $-107^{\circ} 53^{\prime}$ & 1765 & 0.33 \\
\hline $425826-5$ & Morgan & $41^{\circ} 2^{\prime}$ & $-111^{\circ} 39^{\prime}$ & 1545 & 0.53 \\
\hline $056012-2$ & Norwood & $38^{\circ} 8^{\prime}$ & $-108^{\circ} 17^{\prime}$ & 2140 & 0.45 \\
\hline $426404-3$ & Ogden Pioneer Power House & $41^{\circ} 15^{\prime}$ & $-111^{\circ} 57^{\prime}$ & 1326 & 0.67 \\
\hline $426601-4$ & Panguitch & $37^{\circ} 49^{\prime}$ & $-112^{\circ} 26^{\prime}$ & 2027 & 0.49 \\
\hline $426686-4$ & Parowan & $37^{\circ} 50^{\prime}$ & $-112^{\circ} 50^{\prime}$ & 1838 & 0.53 \\
\hline $487260-3$ & Pinedale & $42^{\circ} 52^{\prime}$ & $-109^{\circ} 53^{\prime}$ & 2188 & 0.24 \\
\hline $297323-2$ & Red River & $36^{\circ} 42^{\prime}$ & $-105^{\circ} 24^{\prime}$ & 2646 & 0.40 \\
\hline $057017-2$ & Rico & $37^{\circ} 41^{\prime}$ & $-108^{\circ} 2^{\prime}$ & 2691 & 0.48 \\
\hline $487760-4$ & Riverton USBR & $43^{\circ} 1^{\prime}$ & $-108^{\circ} 23^{\prime}$ & 1420 & 0.22 \\
\hline $057337-5$ & Saguache & $38^{\circ} 5^{\prime}$ & $-106^{\circ} 8^{\prime}$ & 2350 & 0.21 \\
\hline $427590-3$ & Salt Lake City & $40^{\circ} 47^{\prime}$ & $-111^{\circ} 58^{\prime}$ & 1314 & 0.69 \\
\hline $057618-2$ & Shoshone & $39^{\circ} 34^{\prime}$ & $-107^{\circ} 14^{\prime}$ & 1807 & 0.71 \\
\hline $428119-3$ & Spanish Fork Power House & $40^{\circ} 5^{\prime}$ & $-111^{\circ} 36^{\prime}$ & 1436 & 0.71 \\
\hline $427516-2$ & St. George & $37^{\circ} 6^{\prime}$ & $-113^{\circ} 34^{\prime}$ & 823 & 0.43 \\
\hline 057936-2 & Steamboat Springs & $40^{\circ} 30^{\prime}$ & $-106^{\circ} 52^{\prime}$ & 2063 & 0.61 \\
\hline $058204-2$ & Telluride & $37^{\circ} 57^{\prime}$ & $-107^{\circ} 49^{\prime}$ & 2670 & 0.55 \\
\hline $428771-3$ & Tooele & $40^{\circ} 32^{\prime}$ & $-112^{\circ} 18^{\prime}$ & 1469 & 0.65 \\
\hline $058839-4$ & Waterdale & $40^{\circ} 25^{\prime}$ & $-105^{\circ} 12^{\prime}$ & 1585 & 0.28 \\
\hline 029359-2 & Williams & $35^{\circ} 14^{\prime}$ & $-112^{\circ} 11^{\prime}$ & 2057 & 0.40 \\
\hline $429717-2$ & Zion National Park & $37^{\circ} 13^{\prime}$ & $-112^{\circ} 59^{\prime}$ & 1234 & 0.49 \\
\hline
\end{tabular}

on cold season precipitation is also confirmed by the monthly streamflow distribution shown in Fig. 3. This type of streamflow distribution is characteristic of snowgoverned basins in which the majority of the streamflow originates from snowmelt during the warm season months (April-September). The correlation between cold season (October-March) average precipitation and warm season (April-September) total streamflow from
1909 to 1998 in the UCRB is 0.76 . The same type of correlation for the individual stations can be found in Table 2. Based on the previous reasons, April-September streamflow totals from the Lee's Ferry record were used to characterize hydrologic variation in the basin. The distinction between cold and warm season processes was also studied separately on the precipitation time series. For precipitation, three time series were 


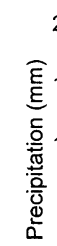
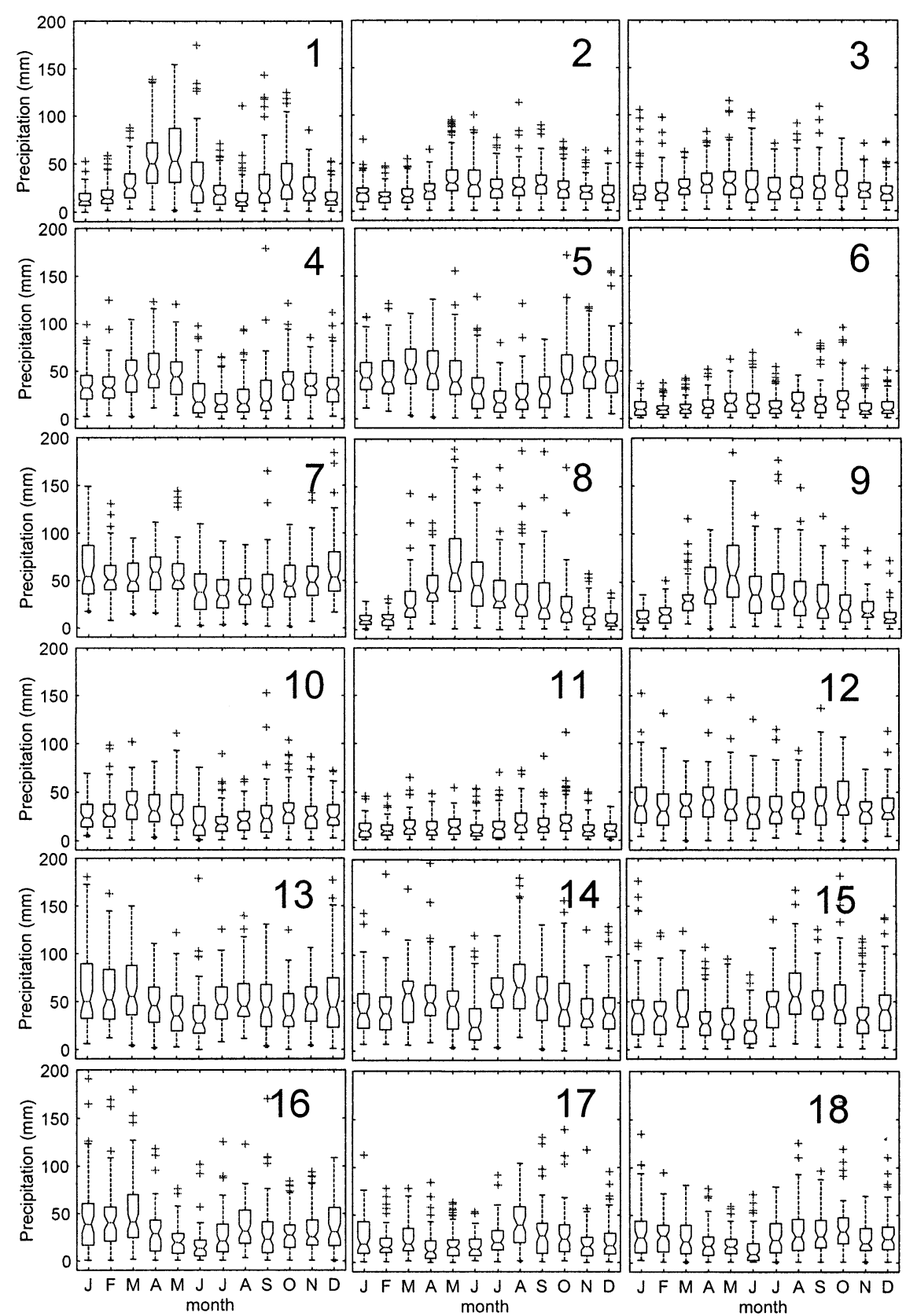

FIG. 1. Monthly distributions (1933-98) from a subset of precipitation stations in the UCRB. The box is composed of the median and the upper and lower quartiles. The magnitudes of the whiskers are computed using the smaller value between 1.5 times the interquartile range or to the extend of the data. Notches represent a robust estimate of the uncertainty about the means for box-to-box comparisons. Values outside the whiskers (outliers) are represented with the symbol "+." Distributions with no outliers show a dot at the whisker's end. Shaded contours are every $500 \mathrm{~m}$ starting at $1500 \mathrm{~m}$. Darker contours represent higher elevations.

prepared for use in latter sections of this study: 1) water year averages (October-September), 2) cold season averages (October-March), and 3) warm season averages (April-September).

Justification of ENSO's influence on the basin is found in the significant correlations $(p \leq 0.01)$ between UCRB's hydroclimatic series (April-September stream- flow, cold season precipitation, warm season precipitation, and water year precipitation averages) and ENSO indicators (Niño1+2, Niño-3, Niño-4, and SOI) shown in Fig. 4. The correlations were computed using lags from 0 to 24 months. Additionally, the monthly ENSO indicators were averaged using 3-12-month windows for each lag. Lags and windows at which significant 


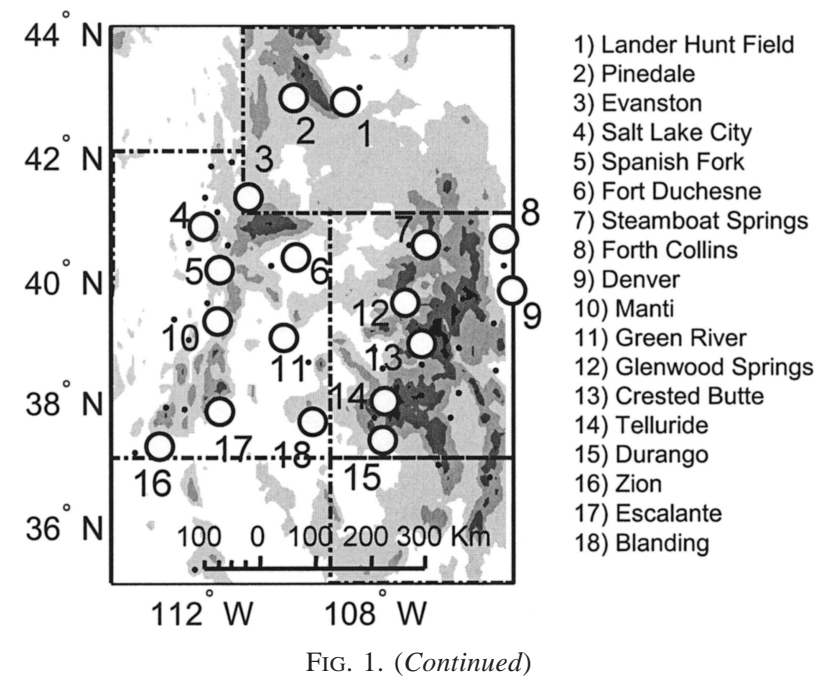

correlations were found are depicted as shaded areas in this figure. Nonsignificant correlations are not shown. For each ENSO indicator variable, there are 10 (thin) rows from top to bottom corresponding to each of the averaging windows (3-12 months). The highest correlations for each ENSO indicator are also shown.

Even though the correlations shown in Fig. 4 are higher for cold season than warm season, it should be remembered that the time series representing high-elevation stations (PC5) represents just a fraction of the total precipitation variance of these stations. Additionally, the lower maximum loadings for the PC representing the high-elevation stations (section $2 \mathrm{~b}$ ) suggest that the ENSO signal during the cold season is significantly less coherent than the broad precipitation variations from the basinwide estimations.

The previous results are verified by looking at the relationship between extreme ENSO events and precipitation and streamflow variations (Fig. 5). In this case, average monthly ENSO indicators for the seven strongest El Niño events (1957/58, 1965/66, 1972/73, 1982/ $83,1986 / 87,1991 / 92$, and 1997/98) and the seven strongest La Niña events (1949/50, 1954/55, 1964/65, 1970/ $71,1973 / 74,1975 / 76$, and 1988/89) selected using the MEI (Wolter 1987) from 1947 to 1998 are plotted along with the monthly averages of precipitation and streamflow in the UCRB. The values from the year previous to each ENSO event are also shown in Fig. 5 as a reference. The most evident feature in Figs. 5a and 5b is the maximum precipitation peak in September during years of strong El Niño events. There is some evidence that the UCRB may be wetter moving toward a strong warm ENSO event, and a secondary precipitation peak of smaller magnitude is also shown in April. This secondary peak is associated with the rising limb of the ENSO indicators. The inclusion of other large events in the future will reduce the uncertainty about the significance of this peak, and a more detailed study would verify its spatial extend. If this peak turns out to be
TABLE 3. Characteristics of the first five precipitation principal components from a subset of stations from Table 2 covering data from 1909 to 1998 .

\begin{tabular}{|c|c|c|c|}
\hline \multirow[b]{2}{*}{ PC } & \multirow[b]{2}{*}{$\begin{array}{c}\text { Variance } \\
\text { explained (\%) }\end{array}$} & \multicolumn{2}{|c|}{ Correlations with Niño-3 SST region } \\
\hline & & $\begin{array}{l}\text { AMJJAS Niño-3 } \\
\text { vs AMJJAS } \\
\text { (warm season) } \text { PC }_{\mathrm{i}}\end{array}$ & $\begin{array}{l}\text { JJASON Niño-3 } \\
\text { vs ONDJFM } \\
\text { (cold season) PC }\end{array}$ \\
\hline $\mathrm{PC}_{1}$ & 28.9 & 0.38 & 0.13 \\
\hline $\mathrm{PC}_{2}$ & 12.7 & -0.13 & 0.30 \\
\hline $\mathrm{PC}_{3}^{2}$ & 11.2 & -0.08 & -0.26 \\
\hline $\mathrm{PC}_{4}$ & 4.0 & 0.04 & 0.04 \\
\hline $\mathrm{PC}_{5}$ & 3.7 & -0.27 & 0.65 \\
\hline $\mathrm{PC}_{6}$ & 3.0 & -0.18 & -0.07 \\
\hline $\mathrm{PC}_{7}$ & 2.3 & -0.08 & -0.25 \\
\hline $\mathrm{PC}_{8}$ & 2.1 & 0.14 & 0.21 \\
\hline $\mathrm{PC}_{9}$ & 2.0 & 0.22 & -0.14 \\
\hline $\mathrm{PC}_{10}$ & 1.7 & 0.03 & -0.03 \\
\hline
\end{tabular}

significant at many precipitation stations, it may provide useful information for future forecasts in the basin.

A similar analysis for a subset of stations highly correlated with ENSO during the cold season at lag four is shown in Fig. 6. In this figure, monthly precipitation from stations with positive correlations (1947-98) between (June-November) Niño-3 SST variations and cold season precipitation (October-November) higher than 0.4 were averaged together to represent the southwestern part of the basin. The southwestern part of the UCRB is expected to be positively correlated with tropical SST variations, while the northwestern part of the basin is expected to present negative correlations (Fig. 2). A similar time series was obtained for the northwestern part of the UCRB, but precipitation from stations with negative correlations with magnitude higher than 0.4 was averaged. As can be seen in Fig. 6a, the increase in cold season precipitation during El Niño
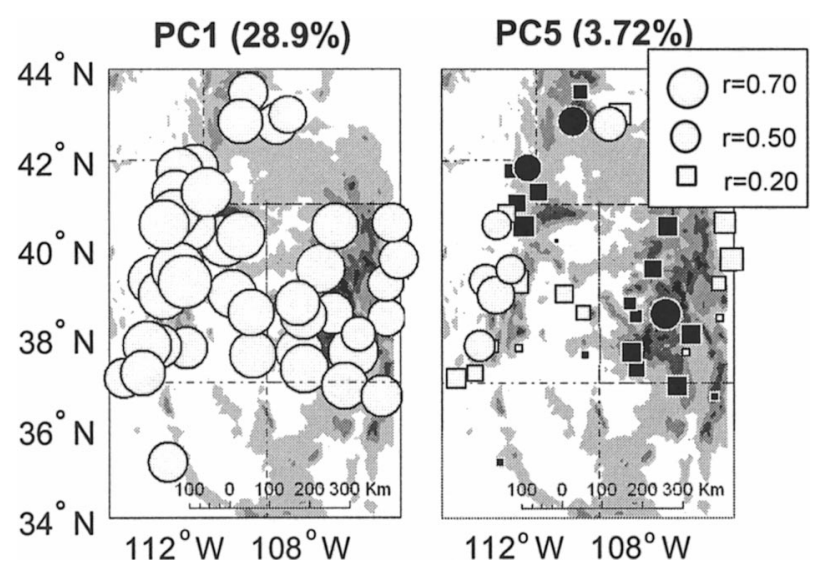

FIG. 2. Principal component loadings, shown as correlations, of the first and fifth principal component of monthly average precipitation in the UCRB from 1909 to 1998. Nonsignificant (significant) correlations at the $5 \%$ level are represented by (circles) squares. Positive (negative) correlations are shown with light (dark) color. Shaded contours are every $500 \mathrm{~m}$ starting at $1500 \mathrm{~m}$. Darker contours represent higher elevations. 

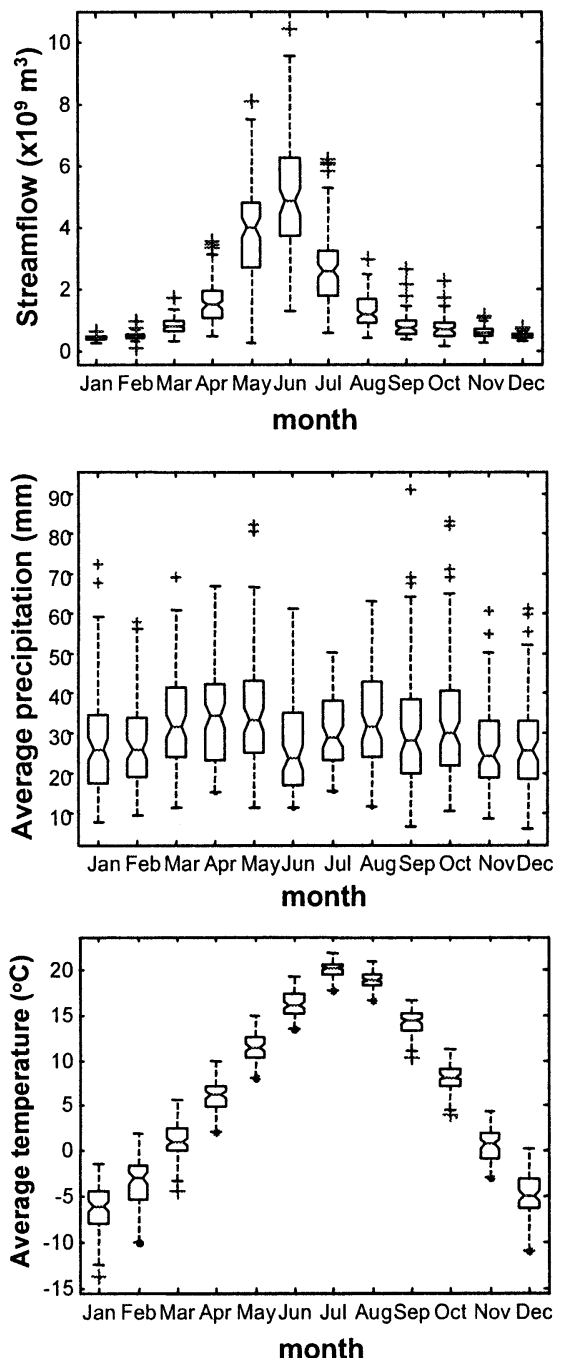

FIG. 3. Monthly distribution of (a) streamflow, (b) average precipitation, and (c) average temperature in the UCBR from 1909 to 1998. The convention for the box plots is the same as in Fig. 1.

events in the southwestern part of the UCRB is greater than the decrease in precipitation in the northwestern part for the same events. During La Niña, there is a slight increase in cold season precipitation in the northwestern parts, and almost normal conditions in the southwestern part of the basin.

Figures 5 and 6 depict an asymmetry in the response of UCRB's precipitation variation to ENSO. In general, the ENSO signature seems to be stronger and more evident in UCRB's precipitation for El Niño than for La Niña. The September precipitation peak observed in the composite of the seven strong El Niño events (Fig. 5) represents about $168 \%$ of the monthly mean for this month, while the November peak in the southernmost part of the basin shown in Fig. 6 represents 178\% of the monthly mean. While part of this intensification could be a reflection of the general tendency of El Niño events to be stronger than La Niña events, it should be

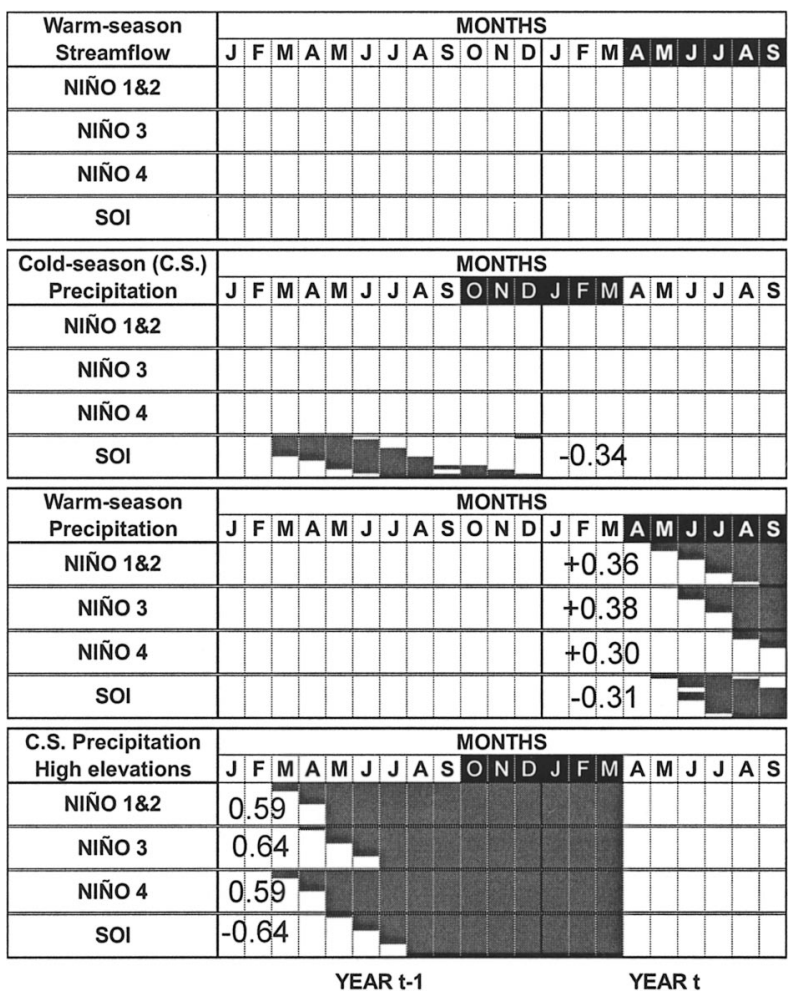

FIG. 4. Shading representing lags and moving windows at which significant correlations (at the $1 \%$ level) between hydroclimatic time series in the UCRB and monthly ENSO indicators are found (see text). From each ENSO monthly variable, 10 time series were prepared for correlation to the UCRB variable, each composed of the moving-window averages from 3 to 12 months in size. The results are shown as 10 (thin) rows for each variable (the top row is for the 3 -month window and the bottom is for the 12 -month window). The highest overall correlation for each shaded region is shown.

mentioned that Figs. 5 and 6 do not provide information about the consistency of the ENSO signal. In other words, moderate La Niña events could still have more consistent response in the UCRB than moderate El Niño events.

\section{b. Results for station data}

In order to provide a verification of the results of ENSO influence on the basinwide precipitation estimates, an alternative analysis is presented in this section using monthly station precipitation data. The station data will also provide a finer spatial resolution, allowing better detection of the ENSO signal found in the highelevation stations during the cold season.

Correlations between June-November Niño-3 SST anomalies (4-month lag) and cold season (OctoberMarch) total precipitation in the UCRB from 1909 to 1998 can be found in Fig. 7a. Correlations between warm season (April-September) Niño-3 SST anomalies and coincident (zero lag) warm season precipitation in the UCRB for the same years are found in Fig. $7 \mathrm{~b}$.

From Fig. $7 \mathrm{a}$ it can be seen that the correlations for 
(a)
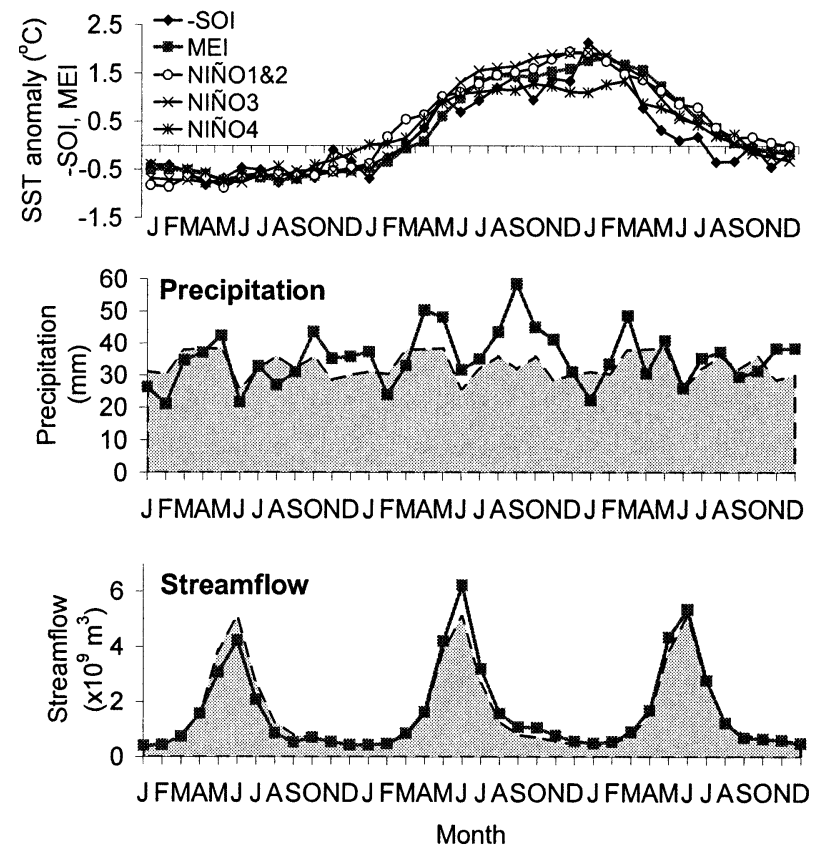

(b)
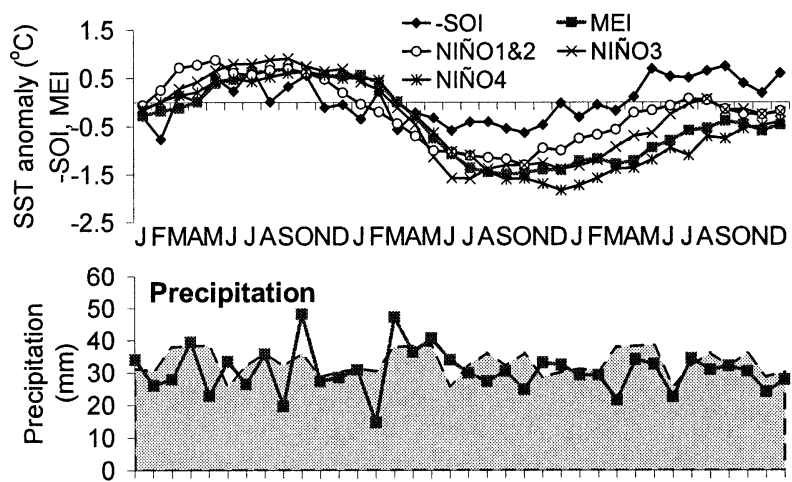

JFMAMJ JASOND J FMAMJ J ASOND J FMAMJ JASOND

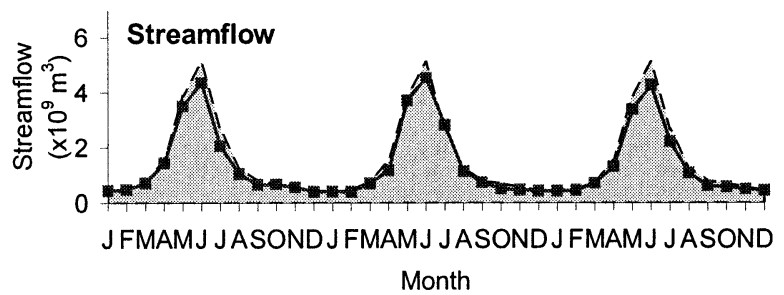

FIG. 5. Average ENSO indicators for the seven strongest (a) El Niño and (b) La Niña events from 1950 to 1998 computed using the Multivariate ENSO Index (Wolter 1987) and average composites of precipitation and streamflow values for the same years. The evolutions of the year previous to each El Niño event are also shown as a reference. In the precipitation and streamflow composites, the monthly means are shown with a dashed line as a reference. (a)
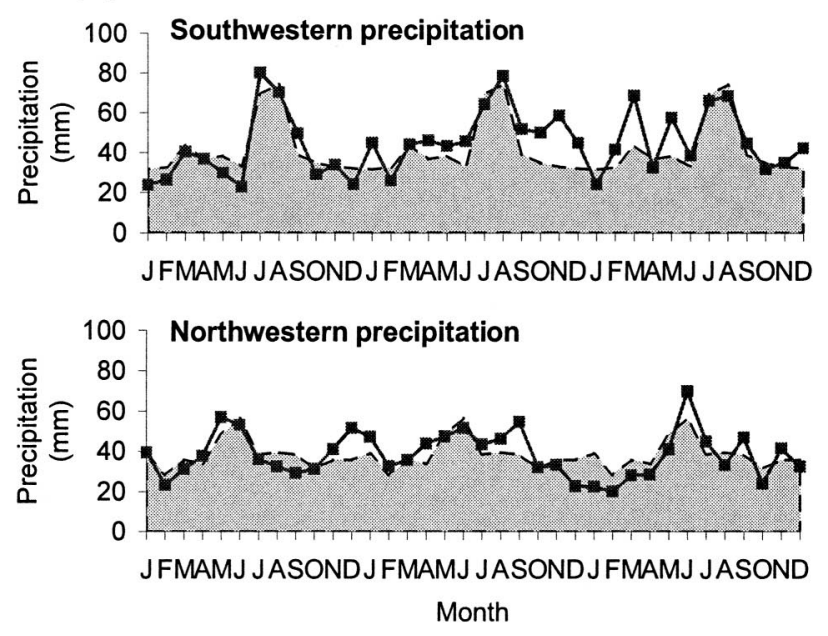

(b)
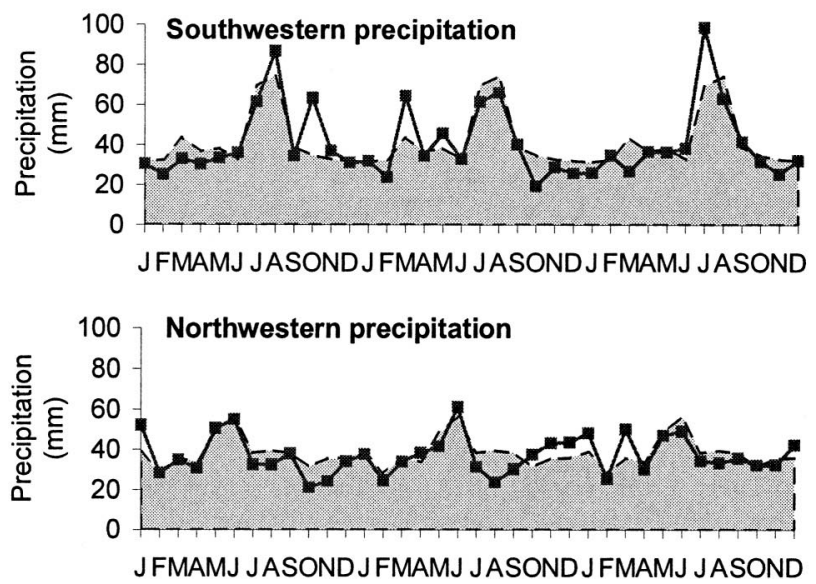

FIG. 6. Average ENSO indicators for the seven strongest (a) El Niño and (b) La Niña events from 1950 to 1998 using the average precipitation of two subsets of stations showing strong $(r \geq 0.4)$ correlations between cold season precipitation and (Jun-Nov) ENSO indicators. The top (bottom) figure represents the southwestern (northwestern) part of the UCRB, which is positively (negatively) correlated with ENSO.

cold season show a band of low negative correlations with ENSO, including sites in the Wasatch Mountain Range, the eastern side of the Wind River Mountain Range, and the western slope of the Rocky Mountains in Colorado. This is consistent with the loading pattern for PC5 shown in Fig. 2. Because there are positive and negative correlations, the basin has a mixed response. This detail is most probably not captured correctly by the basinwide estimates (PC1). The results from the correlation map shown in Fig. 7a are consistent with the analysis of the individual climate divisions, which suggests that the strongest cold season ENSO signal is contained in climate divisions representing the southwestern part of the basin (not shown), a result also in agree- 


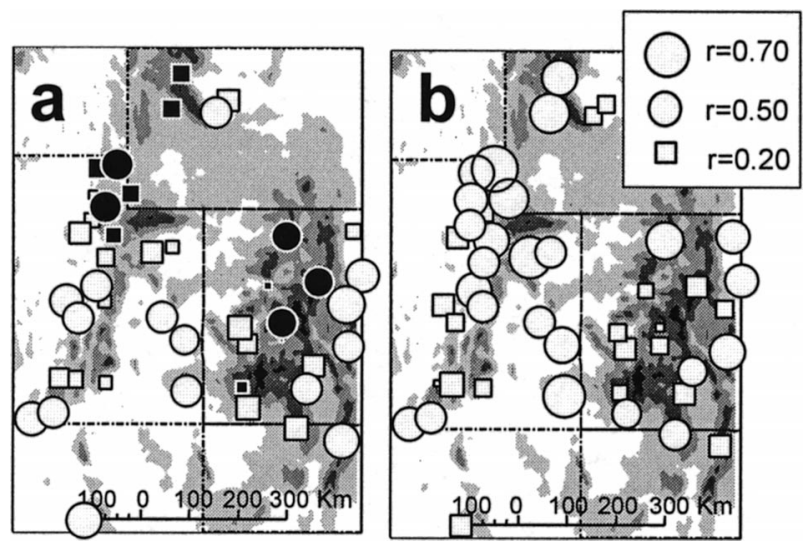

FIG. 7. Correlation coefficients (1909-98) between (a) Jun-Nov Niño-3 SST variations (lag four) and cold season (Oct-Nov) precipitation, and (b) warm season (Apr-Sep) Niño-3 SST variations and coincident (lag zero) warm season precipitation for stations around the UCRB. The symbol convention is the same as in Fig. 2.

ment with other studies (Fig. 1 of Redmond and Koch 1991; Fig. 3.2 of Cayan and Webb 1992).

The results for warm season precipitation response to ENSO (Fig. 7b) showed a stronger and more coherent ENSO signal compared to the results obtained for cold season precipitation. Warm season precipitation is positively correlated with the Niño-3 SST region for all the stations analyzed. Significantly strong correlations (at the $5 \%$ level) were found in some sites on the eastern slopes of the Wasatch and Wind River Mountain Ranges, as well as in most of the lower-elevation stations. Nonsignificant correlations were found, as expected, in the high elevations of the Rocky Mountains.

A warm season precipitation signal associated with ENSO in regions around the UCRB has been found in other studies (Ropelewski and Halpert 1986; Andrade and Sellers 1988; Hereford and Webb 1992; Carleton and Carpenter 1990). In particular, Hereford and Webb (1992) analyzed the historic variation of warm season rainfall in the southern Colorado Plateau (SCP), which covers most of the southern area of the UCRB. Their results showed that warm season rainfall in the SCP increases during El Niño events. The mechanisms behind the intensification of warm season precipitation during the warm phase of ENSO were associated with direct or short-term effects of the subtropical jet stream and above-average SSTs in the eastern North Pacific Ocean by these researchers (Hereford and Webb 1992). Additionally, Ropelewski and Halpert (1986) suggested that the ENSO signal is in phase with the bimodal precipitation cycle (Hereford and Webb 1992) of the Great Basin region (GBR), including the UCRB. These authors found that the strongest ENSO signal in the region occurs in the April-October "season" (Ropelewski and Halpert 1986). Their results showed that $81 \%$ of the El Niño years studied were associated with increased precipitation in the GBR (Ropelewski and Halpert 1986). Higgins et al. (1999) produced composites of seasonal
[June-July-August-September (JJAS)] precipitation percentage anomalies that suggest a moderate increase (between $10 \%$ and $20 \%$ ) in warm season precipitation in most of the UCRB region during El Niño events and vice versa. Another evidence of an almost synchronous ENSO-UCRB connection during the warm season is found in the significant correlations between the first PC of JAS precipitation over the domain $5^{\circ}-35^{\circ} \mathrm{N}$ and $125^{\circ}-80^{\circ} \mathrm{W}$ and JAS precipitation data around the UCRB region found by Higgins and Shi (2001). This component is related by the authors to a characteristic southward shift of the intertropical convergence zone (ITCZ) associated with ENSO (Higgins and Shi 2001).

The asymmetry in UCRB's response for El Niño and La Niña found in the basinwide precipitation estimates from the climate division data was also studied using the station data. The monthly means were removed from the station data, and the differences were expressed as percentages of the same monthly means. The averages of these percentages for the core months of the warm season (JJAS) and the cold season (NDJF) were plotted in Figs. 8-10 for each of the seven strong El Niño and seven strong La Niña events mentioned in section 3a. The results of the composite for the four combinations of both ENSO phases and both precipitation seasons are also shown in Figs. 8h, 9h, 10h, and 11h. El Niño composites for warm and cold seasons (Figs. 8h, 9h) resemble the correlation patterns of Fig. 7. While the La Niña response is generally less defined, the composite for NDJF cold season (Fig. 10h) appears to be inversely related to the correlation pattern of Fig. $6 \mathrm{a}$, and the small positive anomalies during La Niña events in the high elevations of the Rocky Mountains (Fig. 11h) could explain the weak correlations found for this region (Fig. $7 b)$. Cold season precipitation response during El Niño events seems to be characterized by the presence of anomaly regions of opposite sign.

It is interesting to note that two of the largest El Niño events, occurring in 1982/83 and 1997/98 did not produce extensive wetter-than-normal anomalies during the cold season as they did during the warm season months. One possible reason for the lack of cold season response to El Niño events could be the location of the basin compared to the division of the north-south precipitation contrast characteristic of the western United States' ENSO signature. The composites of precipitation anomalies from Figs. $8 \mathrm{~h}$ and $10 \mathrm{~h}$ and the correlation pattern from Fig. 7a confirm that the north-south boundary region of the western U.S. bipolar response to ENSO during the cold season (Ropelewski and Halpert 1986; Andrade and Sellers 1988; Cayan and Webb 1992; Cayan et al. 1999) crosses through the UCRB, producing a mixed response. This boundary region is located at a lower latitude in the eastern part of the UCRB (Rocky Mountains) than in the western part (Wasatch Range), and it is generally different in shape and position for El Niño and La Niña (Cayan et al. 1999). Only when few stations in the high elevations are considered is the 
a) $1957-1958$

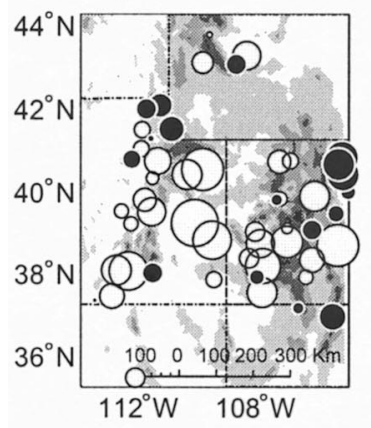

d) $1982-1983$

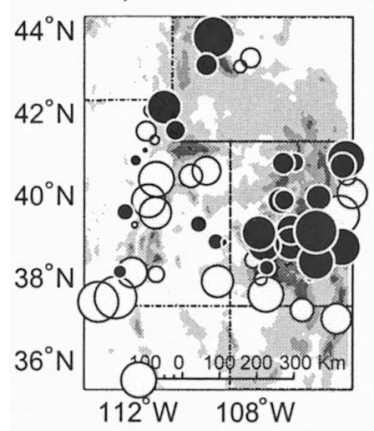

g) $1997-1998$

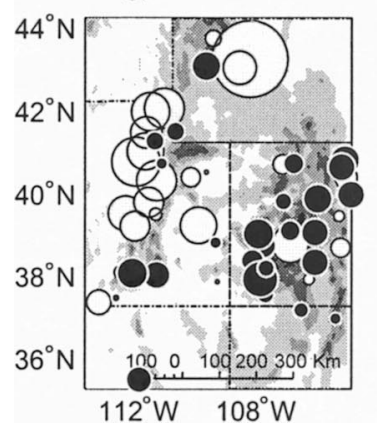

b) $1965-1966$

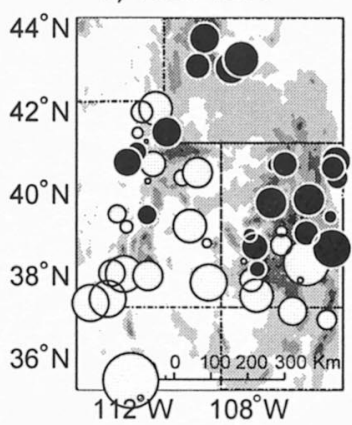

e) $1986-1987$

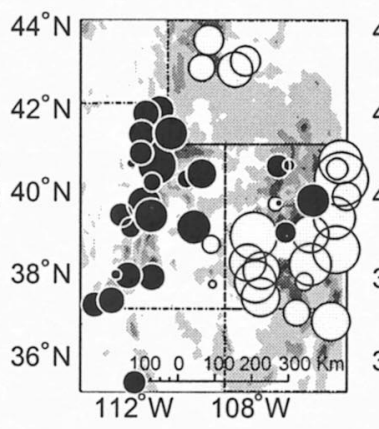

h) average

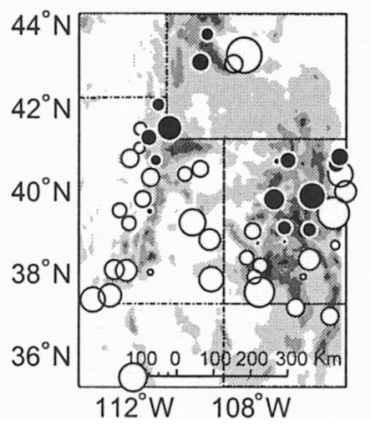

c) $1972-1973$

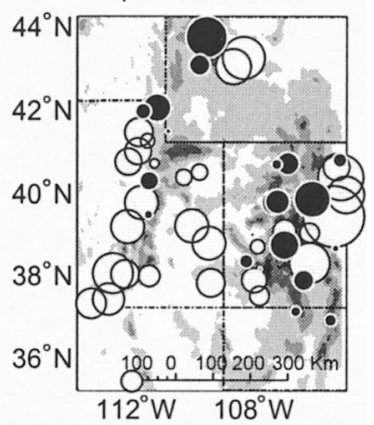

f) $1991-1992$

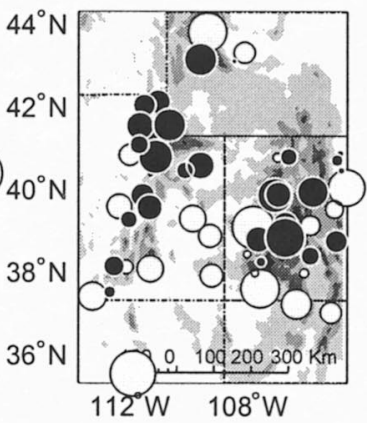

FIG. 8. Nov-Feb (core of cold season) averaged percent anomalies for the seven strongest El Niño events from 1947 to 1998 computed using the Multivariate ENSO Index (Wolter 1987). The averaged values for all the events is also included.

ENSO signal in cold season precipitation in the basin revealed. In contrast, the mechanisms responsible for the increase of warm season precipitation during El Niño events and a moderately dry response during La Niña are most probably associated with ENSO modulations on different climatic mechanisms than the ones responsible for the signal during the cold season.

\section{North Pacific climatic signal}

a. Basinwide hydroclimatic variations at interdecadal timescales

In this section we are interested in studying an apparent modulation of the PDO on ENSO that may be reflected in hydroclimatic variations in the UCRB at interdecadal timescales. To be consistent with the SST data used in the rest of the analysis, a PDO index was constructed using the Kaplan et al. (1998) dataset. The PDO index (Mantua et al. 1997) is defined as the first principal component of monthly SST variation in the North Pacific (poleward of $20^{\circ} \mathrm{N}$ ). The PDO presents a predominant bidecadal oscillation (Biondi et al. 2001), while a pentadecadal signal in also observed during the winter and spring in the North Pacific (Minobe 1997, 1999).

A principal component analysis (PCA) was performed on the covariance matrix of monthly SST data covering a region of the Pacific Ocean poleward of $20^{\circ} \mathrm{N}$ and a time period from 1945 to 1998 . Even though SST data from 1900 to 1944 are available in the Kaplan et 
a) $1957-1958$

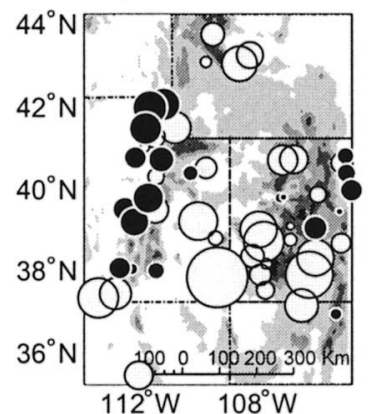

d) $1982-1983$

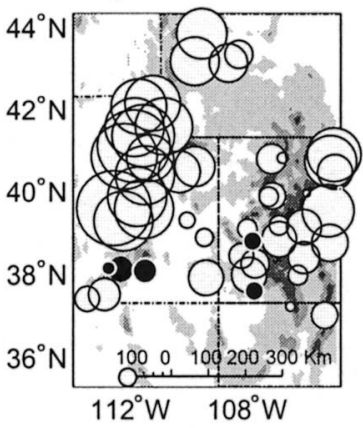

g) $1997-1998$

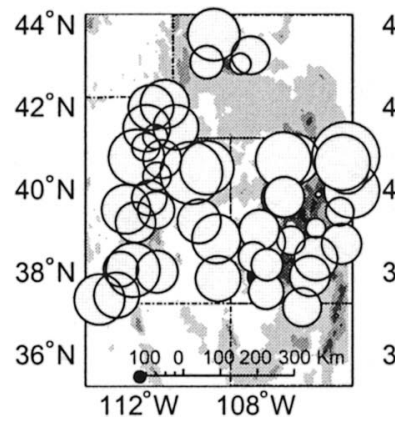

b) $1965-1966$

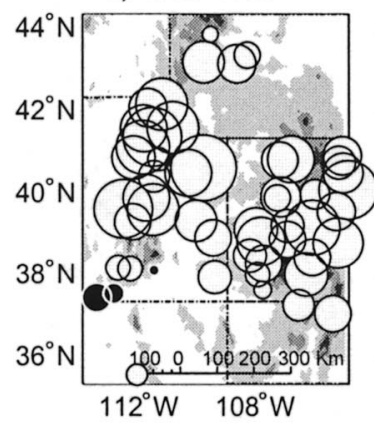

e) $1986-1987$

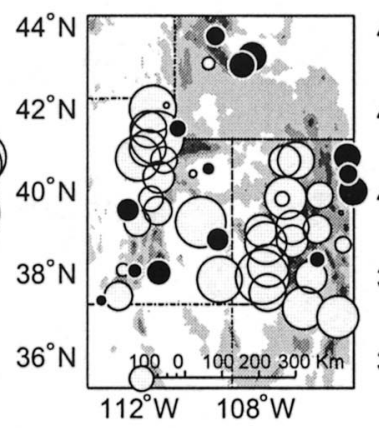

h) average

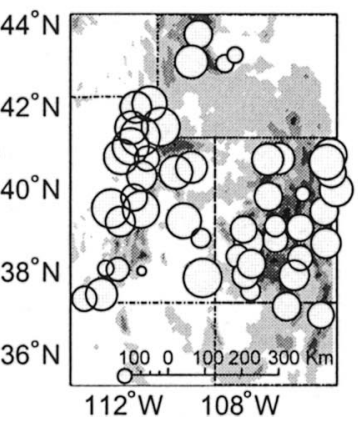

c) $1972-1973$

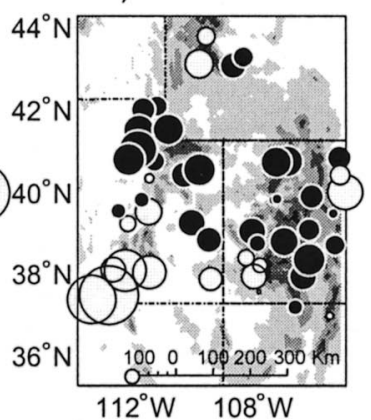

f) $1991-1992$

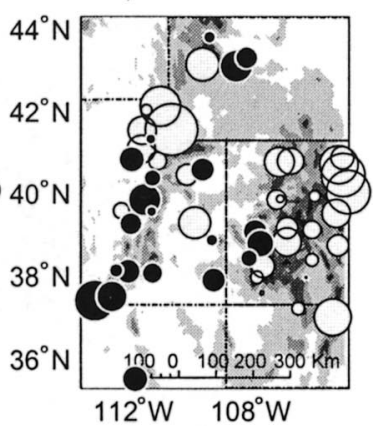

FIG. 9. Same as Fig. 8, but for the core months of the warm season (Jun-Sep).

al. (1998) dataset, the 1945-98 period was chosen because pre-World War II gridded SST datasets are usually less reliable (Minobe and Mantua 1999). The averages, standard deviations, and eigenvectors from the 194598 period were used to produce time representations for the total dataset from 1900 to 1998. That is, the PC's axes were chosen using only the most reliable data. The first PC determined here was named "PDO mode" (PDOm) to distinguish it from the PDO by Mantua et al. (1997), who used a different SST dataset in their analysis. The month-to-month correlation between the PDO and the PDOm time series from 1900 to 1998 is 0.78 .

We looked for shifts in the mean of hydroclimatic variables in the UCRB coincident with sign reversals of the November-March (NDJFM) PDOm. The definition of cold season PDOm over the NDJFM months was selected for consistency with Mantua et al. (1997), since the variations from this period are known to contain significant changes in the mean at decadal timescales. For all other time series, cold season was defined as the period from October through March. Standardized values for the NDJFM PDOm and several hydroclimatic time series for the UCRB are presented in Fig. 12. As can be seen in the figure, the PDOm (NDJFM) experienced significant $(p \leq 0.05)$ changes in the mean around the years 1924/25, 1946/47, and 1976/1977, consistent with the results found by Mantua et al. (1997). The effects of the 1976/77 shift are more clearly observed in UCRB's hydroclimatic variables one year later (1977/78). Hare and Mantua (2000) have found empirical evidence that an additional climate regime shift may have occurred in 1988/89. This latter episode is found in the NDJFM PDO time series by Mantua et al. (1997) 
a) $1949-1950$

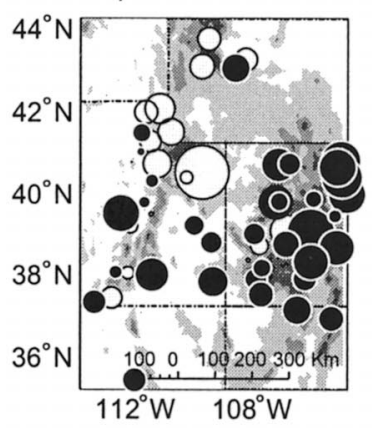

d) $1970-1971$

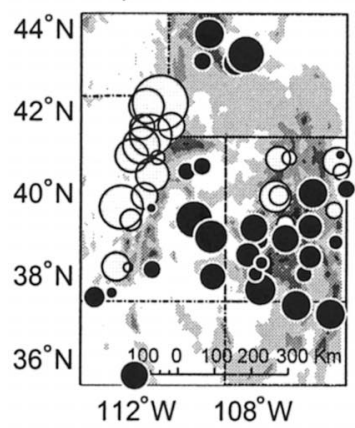

g) $1988-1989$

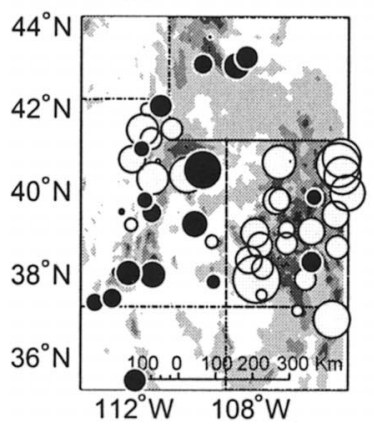

b) $1954-1955$

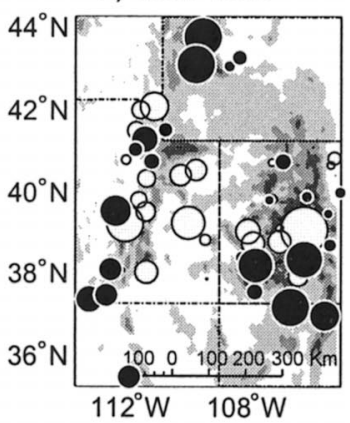

e) $1973-1974$

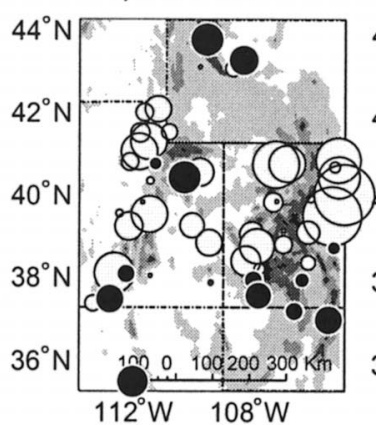

h) average

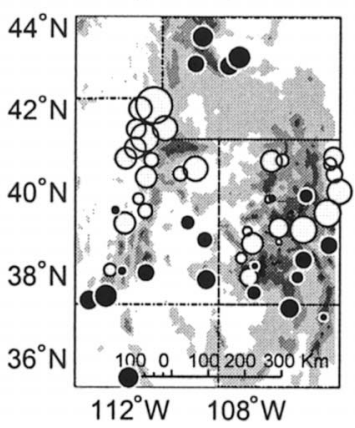

c) $1964-1965$

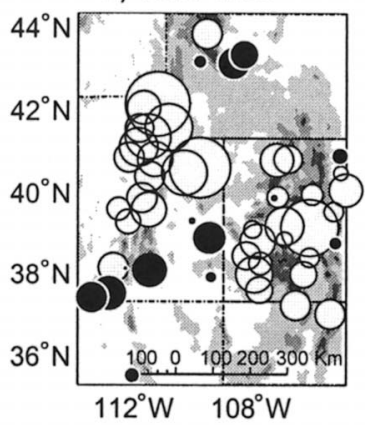

f) $1975-1976$

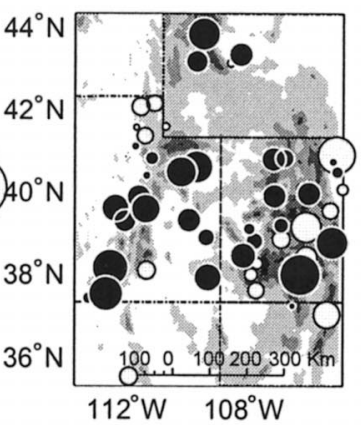

FIG. 10. Same as Fig. 8, but for the seven strongest La Niña events.

(not shown), but it is not significant in the PDOm (NDJFM). The 1988/89 shift is only significant (at the $5 \%$ level) in warm season streamflow (Fig. 12), but it is seen with less definition in some of the time series. The time series which evidence a defined 1988/89 shift (such as in warm season streamflow), also present a wavelike shape in the 1977-98 period composed of the switch from wet to dry conditions in 1988/89 (Fig. 12). This wave can also be seen as a significant ( $p \leq 0.10$ ) increase after 1976/77 in the wavelet (Torrence and Compo 1998) power spectra at periodicities between $\sim 10$ and 16 yr (Fig. 13) for warm season streamflow, water year precipitation, and warm season precipitation. The predominance of a bidecadal signal is evidenced in the NDJFM PDOm, along with a lower-amplitude signal in the pentadecadal period (Fig. 13). Precipitation from the high-elevation stations (PC5) showed a predomi- nance of periodicities in the range 2-8 yr (the same dominant periodicities of ENSO), suggesting an ENSO signature in the variations of PC5.

Except for the 1946/47 shift, there are significant shifts in the mean of most of the UCRB's moisturecontrolled variables coincident with the PDOm shifts, suggesting a connection between the two processes. Warm season precipitation only presents a significant shift in 1976/77. This characteristic variation was also found in cold season and water year averages of the SOI (not shown), which shifted significantly $(p<$ 0.0000 ) only during the $1976 / 77$ shift, validating the connection between warm season precipitation and ENSO suggested in section 3. These shifts were also found in precipitation station (Hidalgo-Leon 2001; Hidalgo and Dracup 2002) and tree ring data (Fig. 14), confirming the connection between UCRB hydrocli- 
a) $1949-1950$

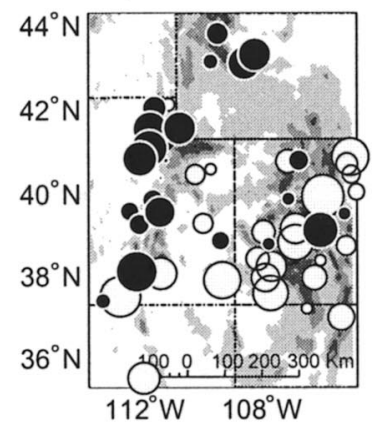

d) $1970-1971$

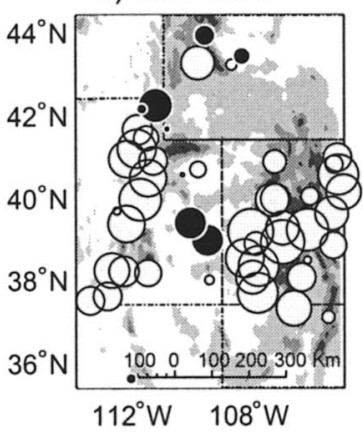

g) $1988-1989$

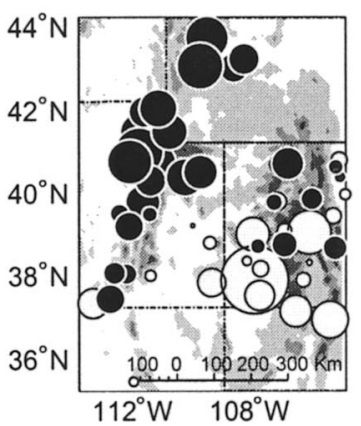

b) $1954-1955$

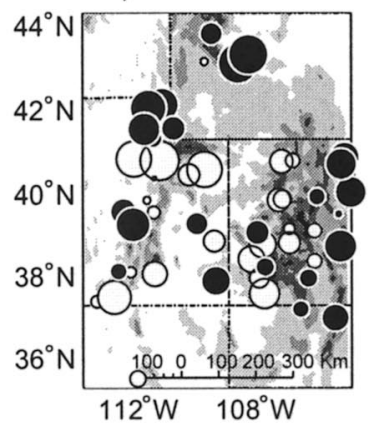

e) $1973-1974$

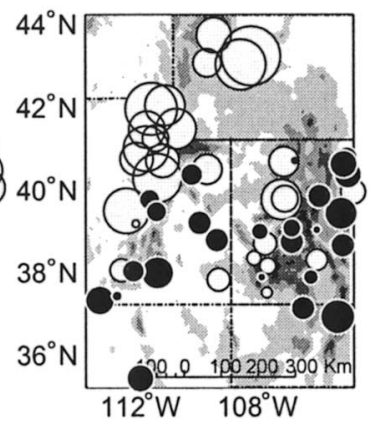

h) average

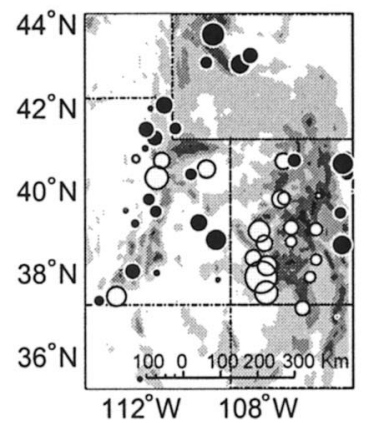

c) $1964-1965$

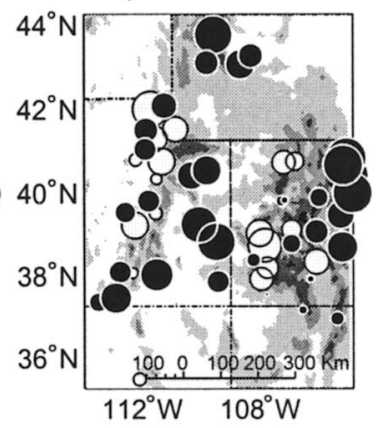

f) $1975-1976$

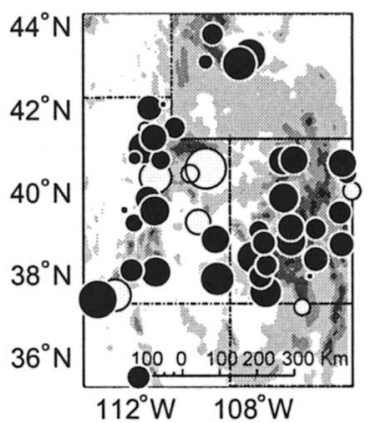

FIG. 11. Same as Fig. 9, but for the seven strongest La Niña events.

matic data and North Pacific decadal-scale variations. Tree ring growth indices from high hydrologic yield areas are known to be associated with hydroclimatic variations in the UCRB (Stockton and Jacoby 1976; Hidalgo et al. 2000, 2001). In Fig. 14 more tree ring chronologies showed a significant shift (at the 5\% level) during the $1924 / 25$ and $1976 / 77$ shifts than during the 1946/47.

The PDOm pattern of variation alternates between positive and negative phases for all consecutive climate regime shifts (Fig. 12). Hydroclimatic variables from other basins known to be strongly affected by the PDO (Fig. 5 of Mantua et al. 1997; Fig. 3 of Hamlet and Lettenmaier 2000) present shifts in the mean coincident with all shifts of the PDO index. This intuitively suggests a modulation by the PDO on the hydroclimatology of these basins. Using data from the period 1933-
93, Gershunov and Barnett (1998) suggested that the modulation of the PDO on U.S. climatic variables could be an expression of the modulation of the PDO on the predominance of each ENSO phase. Strong and consistent El Niño patterns were found on U.S. climatic variables only during the positive phase of the PDO, while the patterns typical of La Niña winters are characteristically strong and consistent only during the negative phase of the PDO (Gershunov and Barnett 1998). In our case, the mean of hydroclimatic variables in the UCRB did not shift during the 1946/47 shift. As a result of this, high (low) PDOm epochs were inversely related to low (high) streamflow for the 1909-46 period, while for the period 1947-98 high (low) PDOm epochs are associated with coincidentally high (low) streamflow periods (Fig. 12). This is particularly important, since it suggests that not all regions influenced 


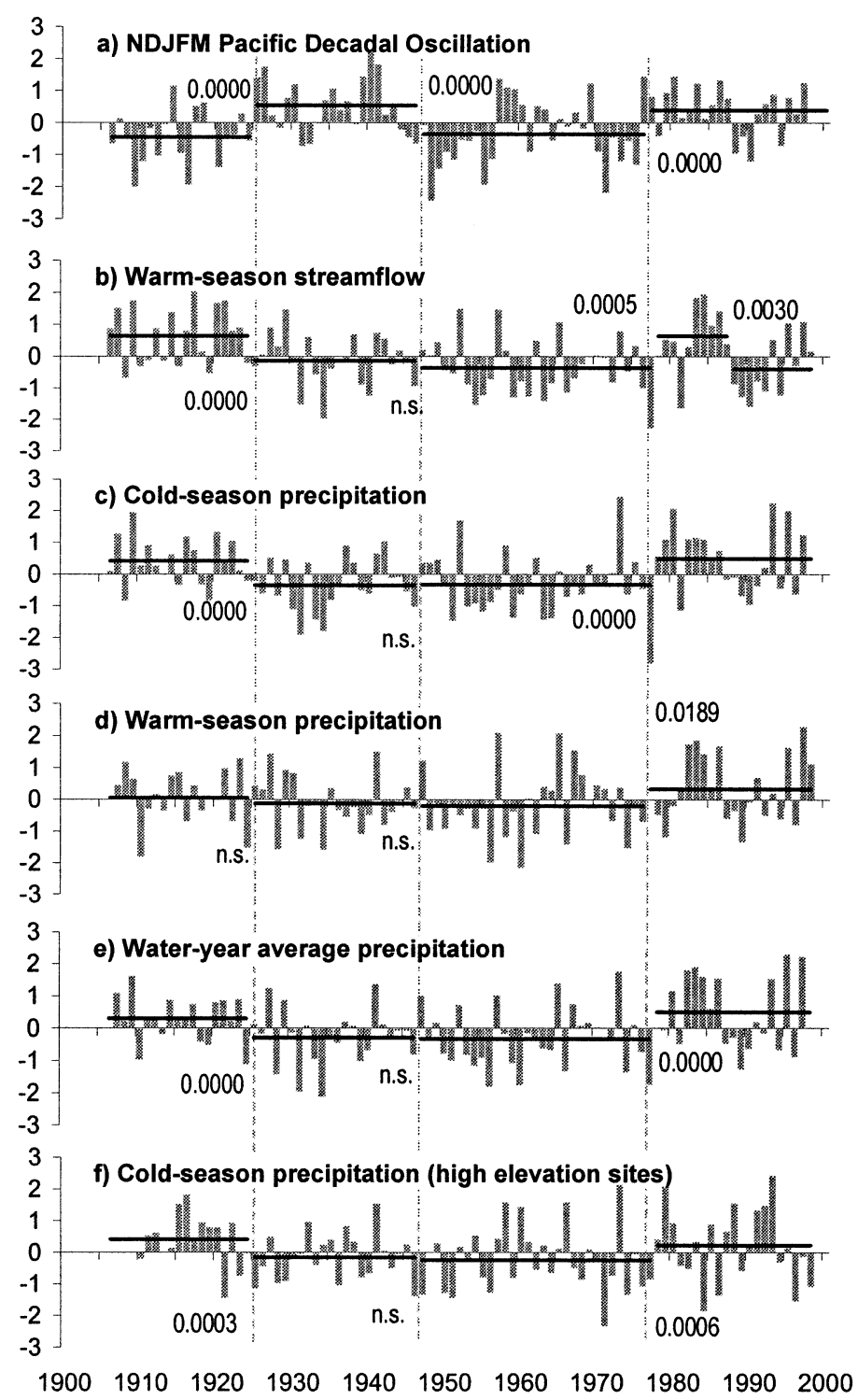

FIG. 12. Standardized time series of Nov-Mar Pacific Decadal Oscillation mode (PDOm), and several hydroclimatic variables in the UCRB. Horizontal lines indicate the mean for each climate epoch defined by times of sign reversals of PDOm. The numbers indicate the probability of no change in the mean at each shift year computed using intervention analysis (Box and Tiao 1975; Box et al. 1994). The "n.s." label was used for probabilities not significant at the $5 \%$ level. The PDOm show significant shifts in the mean in $1924 / 25,1946 / 47$, and 1976/77.

by the North Pacific shifted during the late 1940s PDO shift, and if we assume that there is a modulating role of the PDO on ENSO of the type suggested by Gershunov and Barnett (1998) then the sign of the correlation between ENSO and the UCRB's cold season hydroclimatic variations has changed at some point around the 1946/47 shift. It should be remembered that the basin can have a mixed ENSO response during the cold season (Figs. 2, 7); in this case the basinwide correlations mentioned in the previous sentence are referred to the correlations in the southwestern part of the UCRB during the cold season. Most likely, any modulation of the PDO on ENSO and its response on the UCRB involves a complex mechanism, including modulating cold and warm season precipitation differently, as well as the modulation of the PDO and ENSO on other climatic mechanisms. In the next section we provide some insights about this modulation by studying the response of the UCRB for different phases of ENSO and the PDO. 

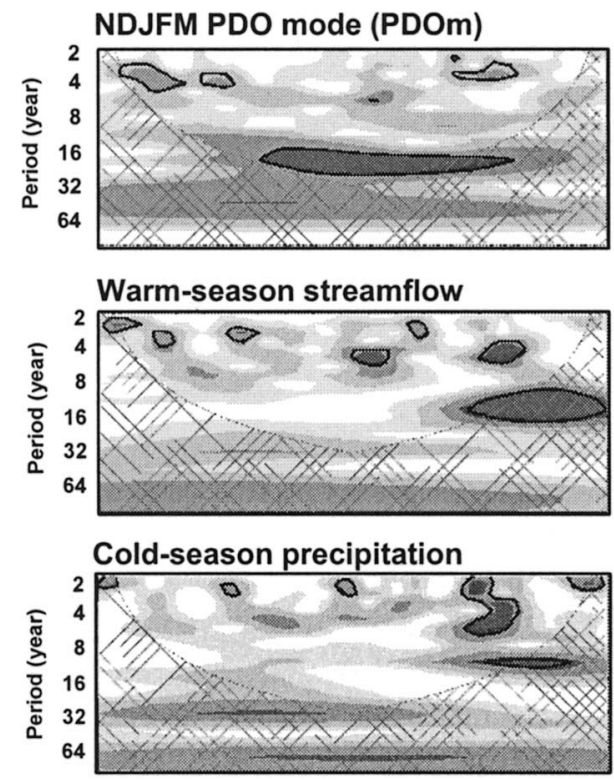

Cold-season precip. (high elevation)
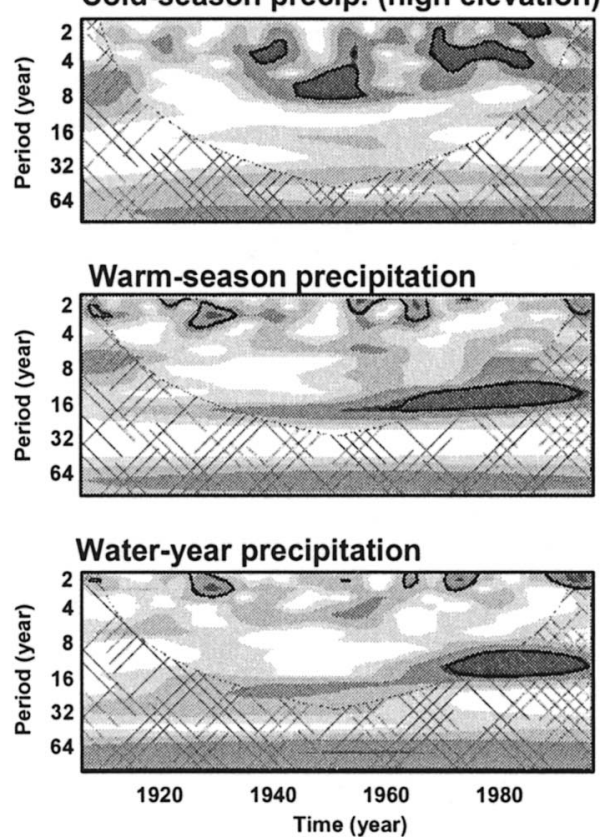

FIG. 13. The wavelet power spectrum of the variables shown in Fig. 12. The contour levels are chosen so that $75 \%, 50 \%, 25 \%$, and $5 \%$ of the wavelet power is above each level, respectively. Darker regions represent higher power. The crosshatched region is the cone of influence, where zero padding has reduced the variance. The black contour is the $10 \%$ significance level, using a red noise (autoregressive lag1) background spectrum. The type of wavelet used is a Morlet wavelet (parameter $=6$, start scale $=2$, scale width $=0.25$ ).

\section{Interpretation of tropical and North Pacific influence by PDO epochs}

In this section we examine changes over time in the strength and consistency of the links between Pacific Ocean and UCRB climatic variations, with the objective of providing insights about the nature of the shifts in the mean of the times series observed in Fig. 12. The station precipitation data will be used to determine changes in the relationships between ENSO and UCRB cold season precipitation through the years. Correlations between June-November averages of Niño-3 SST anomalies and cold season precipitation from 1909 to 1932 (Fig. 15a) suggest that the basin had weak negative correlations during this period. In contrast, the more recent period (1933-98) shows that the lower parts of the basin present more generalized positive correlations with tropical Pacific SST variations characteristic of the ENSO response in the southwestern United States (Fig. $15 \mathrm{~b})$ and an area of negative correlations in the northern part of the basin. The generally positive correlations between warm season precipitation and tropical SST variations discussed in section $3 \mathrm{~b}$ is maintained during both periods (not shown).

A possible explanation for the change in sign of the relationship between ENSO and UCRB cold season processes could be related to a change in the boundary of the north-south bipolar ENSO response. If this boundary was significantly lower from 1909 to 1932, that could explain the negative correlations with tropical SSTs, since the basin would be having the characteristic response of the northwestern United States: wetter-thannormal cold season conditions associated with La Niña and vice versa. There would probably be a transition period of weak correlations around 1933. From 1933 to 1998 the basin has the mixed response found in previous sections (Figs. 2, 7), with the lower part of the basin having significant positive correlations with tropical SSTs and generally weaker negative correlations in the northern parts of the basin (Fig. 15b). This hypothesis could be further verified by studying a larger area to determine the position of the boundary at different periods.

\section{Conclusions and discussion}

As shown throughout this study, the ENSO signal found in warm season precipitation is more consistent at all stations than the ENSO signal in cold season precipitation. ENSO affects warm season precipitation in the basin almost synchronously or at a very small lag. This implies a fast teleconnection triggered by ENSO on warm season circulation patterns or in other summer atmospheric mechanisms. Only when very few stations in the high elevations are considered is the ENSO signal in cold season precipitation revealed. Cold season precipitation is the most important source of streamflow in the UCRB. The correlation patterns between ENSO indicators averaged 4 months in advance and UCRB's cold season precipitation is consistent with other studies (Fig. 3.2 of Cayan and Webb 1992; Fig. 1 of Redmond and Koch 1991).

Using data from the period 1933-93, Gershunov and Barnett (1998) suggested that the modulation of the 

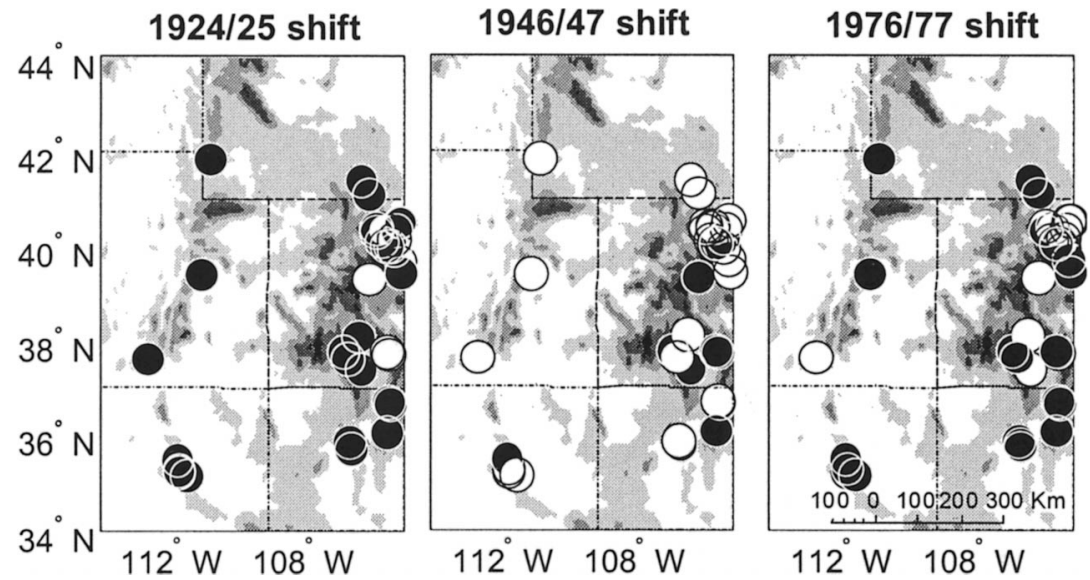

FIG. 14. Shifts in the mean of standardized tree ring growth index in the UCRB. Dark (light) dots indicate sites where the shifts are (not) significant at the 5\% level. Contours are every $500 \mathrm{~m}$ starting at elevation $1500 \mathrm{~m}$.

PDO on U.S. climatic variables could be an expression of the modulation of the PDO on the predominance of each ENSO phase. Strong and consistent El Niño patterns were found on U.S. climatic variables only during the positive phase of the PDO, while the patterns typical of La Niña winters are characteristically strong and consistent only during the negative phase of the PDO (Gershunov and Barnett 1998). In the UCRB, we provided some knowledge about a possible PDO/ENSO modulation of cold season precipitation in the basin. This apparent modulation seems to be accompanied by a general change in the sign of the correlation between ENSO indicators and cold season precipitation in most stations of the basin around 1932/33. This sign change is thought to partially explain hydroclimatic variation in the basin and the observed shifts in the mean of these variables at interdecadal timescales. However, the particular mechanisms behind the change of the correlation signs between ENSO and the basin are still unknown.
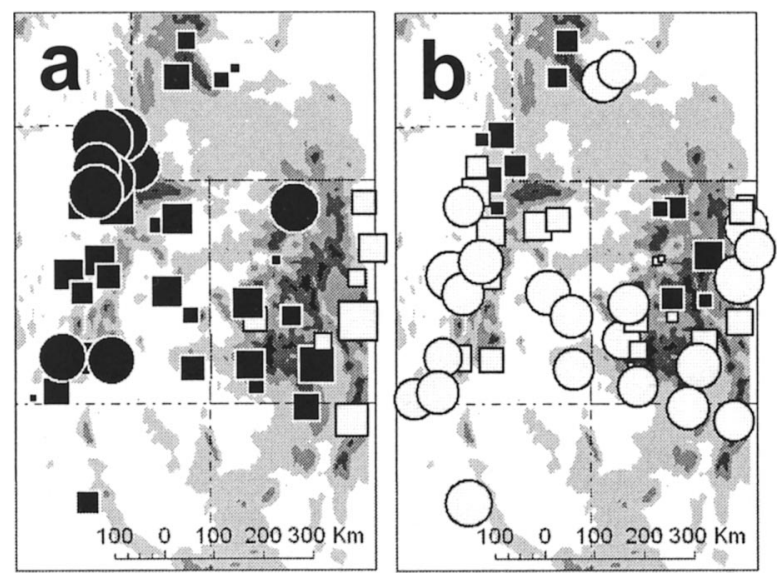

FIG. 15. Correlations between (JJASON) Niño-3 SST variations and cold season precipitation computed for two periods: (a) 1909-32 and (b) 1933-98. The symbol convention is the same as in Fig. 2.
The modulation of the PDO and ENSO on other climatic mechanisms that can influence the UCRB's hydroclimatic variations, such as the changes in the strength of the North American monsoon, predominance of PNA-like patterns, as well as shifts in the subtropical jet and its effects on moisture and summer temperature, is still under investigation. Additionally, it should be noted that the results from the initial part of the records are less reliable, because the hydroclimatic data and the SST data are less reliable at earlier times. More research using paleoclimatic indicators (especially tree rings) could improve our knowledge of these variations beyond the period covered by instrumental records.

In this study we presented some relationships between the Pacific Ocean and the UCRB climate. The results show that these relationships have not been fixed over the twentieth century, but the connection between both regions is modified by changes in the forcing mechanisms at synoptic to global scales (McCabe and Dettinger 1999). The results from this research are useful for the development of forecast models in the UCRB and at the same time provide an alternative way for investigating snowmelt-controlled basins from other regions and their relation to remote forcing mechanisms.

Acknowledgments. This work is partially supported by the University of California Water Resources Center under award WRC-889 and the by National Science Foundation under award NSF 9421030 . The authors express thanks for the comments from Dr. David Silverman, Levi Brekke, the three anonymous reviewers, and the chief editor for the Journal of Hydrometeorology, Dr. Dennis P. Lettenmaier.

\section{REFERENCES}

Alexander, M. A., C. Deser, and M. S. Timlin, 1999: The reemergence of SST anomalies in the North Pacific Ocean. J. Climate, 12, 2419-2433. 
Andrade, E. R., and W. D. Sellers, 1988: El Niño and its effect on precipitation in Arizona and western New Mexico. J. Climatol., 8, 403-410.

Barlow, M., S. Nigam, and E. H. Berbery, 2001: ENSO, Pacific decadal variability, and U.S. summertime precipitation, drought and streamflow. J. Climate, 14, 2105-2128.

Beamish, R. J., 1993: Climate and exceptional fish production of the west-coast of North America. Can. J. Fish. Aquat. Sci., 50, 2270-2291.

— B. E. Riddell, C. M. Neville, B. L. Thomson, and Z. Y. Zhang, 1995: Declines in Chinook salmon catches in the strait of Georgia in relation to shifts in the marine environment. Fish. Oceanogr., 4, 243-256.

_ C. Mahnken, and C. M. Neville, 1997a: Hatchery and wild production of Pacific salmon in relation to large-scale natural shifts in the productivity of the marine environment. ICES J. Mar. Sci., 54, 1200-1215.

_ C. C. Meville, and A. J. Cass, 1997b: Production of Fraser River sockeye salmon (Oncorhynchus nerka) in relation to decadal-scale changes in the climate and the ocean. Can. J. Fish. Aquat. Sci., 54, 543-554.

Biondi, F., A. Gershunov, and D. R. Cayan, 2001: North Pacific decadal climate variability since 1661 . J. Climate, 14, 5-10.

Box, G. E. P., and G. C. Tiao, 1975: Intervention analysis with applications to economic and environmental problems. J. Amer. Stat. Assoc., 70, 70-79.

— - G. M. Jenkins, and G. C. Reinsel, 1994: Time Series Analysis Forecasting and Control. Prentice Hall, 598 pp.

Brown, R. D., and R. O. Braaten, 1998: Spatial and temporal variability of Canadian monthly snow depths, 1946-1995. Atmos.Ocean, 36, 37-54.

Carleton, A. M., and D. A. Carpenter, 1990: Mechanisms of interannual variability of the southwest United States summer rainfall maximum. J. Climate, 3, 999-1015.

Cayan, D. R., 1992: Latent and sensible heat flux anomalies over the northern oceans: The connection to monthly atmospheric circulation. J. Climate, 5, 354-369.

__ and R. H. Webb, 1992: El Niño/Southern Oscillation and streamflow in the western United States. El Niño: Historical and Paleoclimatic Aspects of the Southern Oscillation, H. F. Diaz and V. Markgraf, Eds., Cambridge University Press, 29-68.

_, M. D. Dettinger, H. F. Diaz, and N. E. Graham, 1998: Decadal variability of precipitation over western North America. J. Climate, 11, 3148-3165.

_, K. T. Redmond, and L. G. Riddle, 1999: ENSO and hydrologic extremes in the western United States. J. Climate, 12, 28812893.

Chelliah, M., 1990: The global climate for June-August 1989: A season of near normal conditions in the tropical Pacific. J. Climate, 3, 138-160.

Conversi, A., and S. Hameed, 1997: Evidence for quasi-biennial oscillations in zooplankton biomass in the subarctic Pacific. $J$. Geophys. Res., 102C, 15 659-15 665.

Deser, C., M. A. Alexander, and M. S. Timlin, 1996: Upper-ocean thermal variations in the North Pacific during 1970-1991. J. Climate, 9, 1840-1855.

Dettinger, M. D., and D. R. Cayan, 1995: Large-scale atmospheric forcing of recent trends toward early snowmelt runoff in California. J. Climate, 8, 606-623.

— — _ H. F. Diaz, and D. M. Meko, 1998: North-south precipitation patterns in western North America on interannual-to-decadal timescales. J. Climate, 11, 3095-3111.

,-- G. J. McCabe, and J. A. Morego, 1999: Multiscale hydrologic variability associated with El Niño-Southern Oscillation. El Niño and the Southern Oscillation: Multiscale Variability and Societal Impacts, H. F. Diaz and V. Markgraf, Eds., Cambridge University Press, 113-147.

Díaz, H. F., and R. S. Pulwarty, 1994: An analysis of the time scales of variability in centuries-long ENSO-sensitive records in the last 1000 years. Climatic Change, 26, 317-342.
Downton, M. W., and K. A. Miller, 1998: Relationships between Alaskan salmon catch and North Pacific climate on interannual and interdecadal time scales. Can. J. Fish. Aquat. Sci., 55, 22552265.

Ebbesmeyer, C. C., D. R. Cayan, D. R. McClain, F. H. Nichols, D. H. Peterson, and K. T. Redmond, 1991: 1976 step in Pacific climate: Forty environmental changes between 1968-1975 and 1977-1984. Proceedings of the 7th Annual Pacific Climate (PACLIM) Workshop, April 1990, J. L. Betancourt and V. L. Tharp, Eds., California Department of Water Resources, Interagency Ecological Study Program Tech. Rep. 26, 115-126.

Enfield, D. B., and A. M. Mestas-Nuñez, 1999: Multiscale variabilities in global sea surface temperatures and their relationships with tropospheric climate patterns. J. Climate, 12, 2719-2733.

Gershunov, A., 1998: ENSO influence on intraseasonal extreme rainfall and temperature frequencies in the contiguous United States: Implications for long-range predictability. J. Climate, 11, 3192 3203.

_ teleconnections. Bull. Amer. Meteor. Soc., 79, 2715-2725.

Graham, N. E., 1994: Decadal-scale climate variability in the tropical and North Pacific during the 1970s and 1980s: Observations and model results. Climate Dyn., 10, 135-162.

Hamlet, A. F., and D. P. Lettenmaier, 1999: Columbia River streamflow forecasting based on ENSO and PDO climate signals. ASCE J. Water Resour. Plann. Manage., 125, 331-341.

- , and — 2000: Long-range climate forecasting and its use for water management in the Pacific Northwest region of North America. J. Hydroinf., 2, 163-182.

Hare, S. R., and R. C. Francis, 1995: Climate change and salmon production in the northeast Pacific Ocean. Climate Change and Northern Fish Populations, R. J. Beamish, Ed., Canadian Special Publication of Fisheries and Aquatic Sciences, $121 \mathrm{pp}$.

__ and N. J. Mantua, 2000: Empirical evidence for North Pacific regime shifts in 1977 and 1989. Progress in Oceanography, Vol. 47, Pergamon, 103-145.

Hereford, R., and R. Webb, 1992: Historical variations of warmseason rainfall, southern Colorado plateau, southwestern U.S.A. Climatic Change, 22, 239-256.

Hidalgo, H. G., and J. A. Dracup, 2002: Evidence of the signature of North Pacific multidecadal processes on precipitation/streamflow variations in the upper Colorado River basin. Proceedings of the 6th Biennial Conference of Research on the Colorado Plateau, November 2001, United States Department of the Interior, U.S. Geological Survey, in press.

_, T. C. Piechota, and J. A. Dracup, 2000: Alternative principal components regression procedures for dendrohydrologic reconstructions. Water Resour. Res., 36, 3241-3249.

_ J. A. Dracup, G. M. MacDonald, and J. A. King, 2001: Comparison of tree species sensitivity to high and low extreme hydroclimatic events. Phys. Geogr., 22, 115-134.

Hidalgo-Leon, H., 2001: Tree-ring reconstructions of hydroclimatic variability in the upper Colorado River basin. Ph.D. dissertation, University of California, Los Angeles, $136 \mathrm{pp}$.

Higgins, R. W., and L. A. W. Shi, 2001: Intercomparison of the principal modes of interannual and intraseasonal variability of the North American monsoon system. J. Climate, 14, 403-417.

_, Y. Chen, and A. V. Douglas, 1999: Interannual variability of the North American warm season precipitation regime. J. Climate, 12, 653-680.

_ , J. K. E. Schemm, W. Shiand, and A. Leetmaa, 2000: Extreme precipitation events in the western United States related to tropical forcing. J. Climate, 13, 793-820.

Hollowed, A. B., S. R. Hare, and W. S. Wooster, 2001: Pacific Basin climate variability and patterns of northeast Pacific marine fish production. Progress in Oceanography, Vol. 49, Pergamon, 257282.

Horner, R. A., D. L. Garrison, and F. G. Plumley, 1997: Harmful algal blooms and red tide problems on the US west coast. Limnol. Oceanogr., 42, 1076-1088. 
Ingraham, W. J., R. K. Reed, J. D. Schumacher, and S. A. Macklin, 1991: Interannual variability of circulation in the Gulf of Alaska in relation to water properties and fisheries resources. Eos, Trans. Amer. Geophys. Union, 72, 257-264.

JISAO, cited 1999: Joint Institute for the Study of Atmosphere and Ocean. [Available online at http://tao.atmos.washington.edu/ main.html.]

Josberger, E. G., W. J. Campbell, P. Gloersen, A. T. C. Chang, and A. Rango, 1993: Snow conditions and hydrology of the upper Colorado River basin from satellite passive microwave observations. Ann. Glaciol., 17, 322-326.

Kahya, E., and J. A. Dracup, 1993: U.S. streamflow patterns in relation to El Niño-Southern Oscillation. Water Resour. Res., 29, 2491-2503.

— events on streamflows in the Pacific Southwest of the United States. J. Climate, 7, 965-976.

Kaplan, A., M. Cane, Y. Kushnir, A. Clement, M. Blumenthaland, and B. Rajagopalan, 1998: Analyses of global sea surface temperature. J. Geophys. Res., 103, 567-589.

Kerr, R. A., 1992: Unmasking a shifty climate system. Science, 255, 1508-1510.

Kiladis, G., and H. F. Diaz, 1989: Global climatic anomalies associated with extremes of the Southern Oscillation. J. Climate, 2, 1069-1090.

Latif, M., and T. P. Barnett, 1996: Decadal climate variability over the North Pacific and North America: Dynamics and predictability. J. Climate, 9, 2407-2423.

Liu, Z. Y., and Y. Zhang, 1999: Propagation and mechanism of decadal upper-ocean variability in the North Pacific. Geophys. Res. Lett., 26, 739-742.

Mantua, N. J., S. R. Hare, J. M. Wallace, and R. C. Francis, 1997: A Pacific interdecadal climate oscillation with impacts on salmon production. Bull. Amer. Meteor. Soc., 78, 1069-1079.

McCabe, G. J., and A. G. Fountain, 1995: Relations between atmospheric circulation and mass-balance at south cascade glacier, Washington, USA. Arct. Alp. Res., 27, 226-233.

— of ENSO teleconnections with precipitation in the western United States. Int. J. Climatol., 19, 1399-1400.

McGowan, J. A., D. R. Cayan, and L. M. Dorman, 1998: Climateocean variability and ecosystem response in the northeast Pacific. Science, 281, 210-217.

Mestas-Nuñez, A. M., and D. M. Enfield, 1999: Rotated global modes of non-ENSO sea surface temperature variability. J. Climate, 12, 2734-2746.

Minobe, S., 1997: A 50-70 year climatic oscillation over the North Pacific and North America. Geophys. Res. Lett., 24, 683-686.

$\ldots$, 1999: Resonance in bidecadal and pentadecadal climate oscillations over the North Pacific: Role in climate regime shifts. Geophys. Res. Lett., 26, 855-858.

_ atmospheric and oceanic variability over the North Pacific. Progress in Oceanography, Vol. 43, Pergamon, 163-192.

Namias, J., 1969: Seasonal interactions between the North Pacific Ocean and the atmosphere during the 1960's. Mon. Wea. Rev., 97, 173-192.

NCDC, cited 1999: Climate Division Data Base. National Climatic Data Center. [Available online at http://www.ncdc.noaa.gov.]

Niebauer, H. J., 1998: Variability in Bering Sea ice cover as affected by a regime shift in the North Pacific in the period 1947-1996. J. Geophys. Res., 103, 27 717-27 737.

Nigam, S., M. Barlow, and E. H. Berbery, 1999: Analysis links Pacific decadal variability to drought and streamflow in the United States. Eos, Trans. Amer. Geophys. Union, 80, 621-625.

NOAA, cited 1997: Contributors of the International Tree-Ring Data Bank. IGBP PAGES/World Data Center for Paleoclimatology,
NOAA/NGDC Paleoclimatology Program, Boulder, CO. [Available online at http://www.ngdc.noaa.gov.]

Parker, D. E., P. E. Jones, C. K. Folland, and A. Bevan, 1994: Interdecadal changes of surface temperature since the late nineteenth century. J. Geophys. Res., 99, 373-399.

Pelto, M. S., 1996: Annual net balance of North Cascade glaciers. J. Glaciol., 42, 3-9.

Piechota, T. C., and J. A. Dracup, 1996: Drought and regional hydrologic variation in the United States: Associations with El Niño-Southern Oscillation. Water Resour. Res., 32, 1359-1373. _ and __ 1999: Long range streamflow forecasting using El Niño-Southern Oscillation indicators. J. Hydrol. Eng., 4, 144151.

_ _ — , and R. G. Fovell, 1997: Western U.S. streamflow and atmospheric circulation patterns during El Niño Southern Oscillation. J. Hydrol., 201, 249-271.

Redmond, K. T., and R. W. Koch, 1991: Surface climate and streamflow variability in the western United States and their relationship to large-scale circulation indices. Water Resour. Res., 27, 2381-2399.

Ropelewski, C. F., and M. S. Halpert, 1986: North American precipitation and temperature patterns associated with El Niño-Southern Oscillation (ENSO). Mon. Wea. Rev., 114, 2352-2362.

—_ and - 1989: Precipitation patterns associated with the high index phase of the Southern Oscillation. J. Climate, 2, 268-284.

Stockton, C. W., and G. C. Jacoby Jr., 1976: Long-term surface-water supply and streamflow trends in the upper Colorado River basin based on tree-ring analysis. Lake Powell Research Project Bulletin 18, Institute of Geophysics and Planetary Physics, University of California, Los Angeles, $70 \mathrm{pp}$.

Swetnam, T. W., and J. L. Betancourt, 1998: Mesoscale disturbance and ecological response to decadal climatic variability in the American Southwest. J. Climate, 11, 3128-3147.

Torrence, C., and G. P. Compo, 1998: A practical guide to wavelet analysis. Bull. Amer. Meteor. Soc., 79, 61-78.

Trenberth, K. E., 1990: Recent observed interdecadal climate changes in the Northern Hemisphere. Bull. Amer. Meteor. Soc., 71, 988993.

__ and J. W. Hurrell, 1994: Decadal atmosphere-ocean variations in the Pacific. Climate Dyn., 9, 303-319.

USBR, cited 1998: Biological Assesment Project. United States Bureau of Reclamation. [Available online at http://www.usbr.gov/ main/index.html.]

Volodin, E. M., and V. Y. Galin, 1999: Interpretation of winter warming on Northern Hemisphere continents in 1977-94. J. Climate, 12, 2947-2955.

Weinheimer, A. L., and D. R. Cayan, 1997: Radiolarian assemblages from Santa Barbara Basin sediments: Recent interdecadal variability. Paleoceanography, 12, 658-670.

Wiles, G. C., R. D. D’Arrigo, and G. C. Jacoby, 1998: Gulf of Alaska atmosphere-ocean variability over recent centuries inferred from coastal tree-ring records. Climatic Change, 38, 289-306.

Wolter, K., 1987: The Southern Oscillation in surface circulation and climate over the tropical Atlantic, eastern Pacific, and Indian Oceans as captured by cluster analysis. J. Climate Appl. Meteor., 26, 540-558.

Zhang, R. H., and S. Levitus, 1997: Structure and cycle of decadal variability of upper-ocean temperature in the North Pacific. $J$. Climate, 10, 710-727.

— L. L. M. Rothstein, and A. J. Bussalacchi, 1998: Origin of upperocean warming and El Niño change on decadal scales in the tropical Pacific Ocean. Nature, 391, 879-883.

Zhang, Y., J. M. Wallace, and N. Iwasaka, 1996: Is climate variability over the North Pacific a linear response to ENSO? J. Climate, 9, 1468-1478.

, —_ , and D. S. Battisti, 1997: ENSO-like interdecadal variability. J. Climate, 10, 1004-1020. 